\title{
A needs assessment of West Virginia environmental educators: West Virginia Environmental Education Association and West Virginia University County Extension Agents
}

Amanda Rae Swecker See

West Virginia University

Follow this and additional works at: https://researchrepository.wvu.edu/etd

\section{Recommended Citation}

See, Amanda Rae Swecker, "A needs assessment of West Virginia environmental educators: West Virginia Environmental Education Association and West Virginia University County Extension Agents" (2009). Graduate Theses, Dissertations, and Problem Reports. 2905.

https://researchrepository.wvu.edu/etd/2905

This Thesis is protected by copyright and/or related rights. It has been brought to you by the The Research Repository @ WVU with permission from the rights-holder(s). You are free to use this Thesis in any way that is permitted by the copyright and related rights legislation that applies to your use. For other uses you must obtain permission from the rights-holder(s) directly, unless additional rights are indicated by a Creative Commons license in the record and/ or on the work itself. This Thesis has been accepted for inclusion in WVU Graduate Theses, Dissertations, and Problem Reports collection by an authorized administrator of The Research Repository @ WVU. For more information, please contact researchrepository@mail.wvu.edu. 
A Needs Assessment of West Virginia Environmental Educators:

West Virginia Environmental Education Association and West Virginia University County Extension Agents

Amanda Rae Swecker See

Thesis submitted to the Davis College of Agriculture, Forestry, and Consumer Sciences at West Virginia University

In partial fulfillment of the requirements

For the degree of

\author{
Master of Science \\ in \\ Recreation, Parks and Tourism Resources
}

David Smaldone, Ph.D., Chair

Steve Selin, Ph.D.

Deborah A. Boone, Ph.D.

Morgantown, West Virginia

2009

Keywords: Environmental Education, Extension, Needs Assessment 


\begin{abstract}
A Needs Assessment of West Virginia Environmental Educators:

West Virginia Environmental Education Association and

West Virginia University County Extension Agents
\end{abstract}

Amanda Swecker See

West Virginia is a state full of a variety of environmental education (EE) programs - both formal and nonformal. However, in order to be effective, educators must have the most updated and user friendly resources readily accessible through various supporting organizations or agencies. The WVEEA is a new state-wide group dedicated to improving EE programs, and supporting EE through its members.

The ultimate goal of EE programs is to improve environmental literacy and foster environmentally responsible behavior. Environmental literacy gives people the awareness, knowledge, ability, motivation, commitment and skill to work with others to resolve environmental problems and prevent new ones. EE activities can also improve communication, group processes, and problem-solving skills to help prepare a society-ready youth.

This present study examined the needs of environmental educators in West Virginiadefined as those individuals associated with the WVEEA. The purpose of this study is to identify those individuals and organizations that provide EE in West Virginia and gather specific information about EE providers in WV (types of programs provided, audiences, etc). In addition, the educators were asked about barriers and needs, in order to enhance their programs for the future and to aid in their professional development.

In August and September 2008, surveys were mailed to all the contacts in the WVEEA's database and every West Virginia extension agent. These contacts were asked to fill out the surveys and mail them back. The survey included questions that addressed program descriptions, demographics, resource and professional development needs and program barriers. 


\section{Table of Contents}

Abstract__ ii

Table of Contents __ iii

List of Tables __ v

Chapter 1 - Introduction __ 1

Introduction

Purpose

Research Questions _ 5

Chapter 2 - Literature Review __ 6

Environmental Education 6

Formal versus Nonformal Education__ 8

Needs Assessment __ 9

Capacity Building __ 11

The Role of Extension Agents___ 13

Previous Findings from other EE Needs Assessments __ 15

Chapter 3 - Methodology _ 19

Research Questions _ 19

Population 19

Study Area__ 20

Data Collection Procedures __ 20

Instrumentation

Delimitations __ 22

Limitations__ 22

Chapter 4 - Results _ 23

Environmental Education Program Description _ 23

Extension Agents' Knowledge of EE in County __ 29

Barriers \& Opportunities - Comparing EE and Extension Respondents ___ 31

WVEEA Organizational Needs___ 37

Chapter 5 - Discussion _ 44

Conclusions _ 50

Recommendations _ 52

References _ 54

Appendix__ 58 
WVEEA Questionnaire 58

West Virginia University Extension Agent Questionnaire 67 


\section{List of Tables}

Table

Page

4.1 EE Organization Category 24

4.2 Environmental Issues Addressed by Programs 25

4.3 Type of EE Programs Offered 26

4.4 EE Programs Conducted per Year 26

$\begin{array}{lll}4.5 & \text { Program Participants } & 27\end{array}$

4.6 WV Curriculum Addressed 28

4.7 Annual Operating Budget 29

4.8 Awareness of EE in County 30

4.9 Materials Provided to County EE Programs 31

4.10 Program Barriers 33

4.11 Professional Development Opportunities 36

4.12 Capacity Building Training Needs 38

4.13 Organization's Sources of Information 40

4.14 WVEEA's Role 41

4.15 Membership Base for WVEEA 42

4.16 Benefits of Joining WVEEA 43 


\section{Chapter 1. Introduction}

\section{Introduction}

The Environmental Education and Training Partnership (2002) noted that professional development enables educators and decision makers to effectively use environmental education as a tool for improving teaching and learning and achieving a healthy and sustainable environment. West Virginia is a state full of a variety of environmental education programs both formal and nonformal. The purposes of environmental education programs in the state are to inform and educate various audiences about different types of environmental issues.

The North American Association of Environmental Educators (NAAEE) believes the purpose of environmental education is teaching people how to think about the environment, not what to think, and learning how to use high-quality teaching methods to show people how to make a difference in the world through a positive, nonconfrontational approach (2009). Education is defined as the knowledge and development resulting from an educational process (The American Heritage College Dictionary, 1993). Environmental educators strive to help participants in their programs build a strong knowledge base of the field's curricula. These programs can be delivered both in a school setting (formal) and outside of a school or community setting (nonformal).

Recent focus on national concerns about our decreased connection to nature and the environment, increasing obesity rates (especially in children) and climate change has brought new attention to environmental programs and education (IPCC, 2007; Louv, 2005; Maller et al., 2008). A new study reports that one in five four-year olds in America is obese, over a half a million total (Associated Press, 2009). In June of 2008, a key Congressional House committee 
blessed a bill that would provide money to help states develop environmental lessons and train teachers to deliver them. In addition, the National Environmental Education Foundation, which teams up with schools and other institutions to promote green curricula, has seen the number of its partners jump from 330 in 2006 to 1,855 in 2008 (King, 2008).

In his book Last Child in the Woods, Richard Louv (2005) suggests the term naturedeficit disorder to describe what many of today's children are experiencing. Environmental education programs could potentially help alleviate some of the side effects of nature deficit disorder. Louv describes nature deficit disorder as a way to think about the problem of the disconnect with nature that children are experiencing today. One side effect of this is the decreasing levels of physical activity that children participate in each day. One parent that Louv (2005) interviewed commented that “as far as physical fitness goes, today's kids are the sorriest generation in the history of the United States (p. 11)." As the federal and state governments and local school boards began to push for higher test scores in the early part of this decade, about a dozen states have cut back or even canceled recess, which is often the only time children get the opportunity to participate in physical activity at school (Louv, 2005). This is all happening in a country where $40 \%$ of five to eight year olds suffer some sort of cardiac risk, such as obesity (Louv, 2005).

This disturbing trend in overweight children is a fairly recent one. In a 1971-1974 survey, only $4 \%$ of children between the ages of six and 11 were considered overweight, while $18.8 \%$ of children at this age were overweight in a more recent 2003-2004 survey (Iannelli, 2008). The No Child Left Behind Act (NCLB) fundamentally changed the way that education is delivered in this country (No Child Left Inside, 2009). It has defined the core content that all students in the United States must learn to be considered proficient at each grade level. As of 
2007, this includes content standards in reading, math, and science (No Child Left Inside, 2009). Some health officials have worried about unintended side effects of the NCLB Act as schools struggle to meet the law's mandates. The fear is that less and less time will be allotted for physical activity and even recess, which fuels the growing obesity rate in children (Doheny, 2005). The No Child Left Inside Act can help address the problem of childhood obesity by increasing the time students spend learning about nature, both in and outside the classroom. Such lessons are often more engaging to students and often lead them to become more active outside (No Child Left Inside, 2009).

In addition to reduced connection with nature and reduced levels of physical activity, another reason environmental education has become popular hot topic is the increasing awareness of the negative effects of climate change. Many observations indicate that the world's climate has changed during the 20th century (Green Facts, 2007; IPCC, 2007). The average surface temperature has increased by about one degree Fahrenheit, snow cover and ice have decreased and the sea level has risen by four to eight inches. Climate has and will always vary for natural reasons; however, human activities are increasing significantly the concentrations of some gases in the atmosphere (IPCC, 2007). Projected changes in climate are expected to have both beneficial and adverse effects on water resources, agriculture, natural ecosystems and human health. But the larger the changes in climate, the more the adverse effects should dominate (Green Facts, 2007). Organizations like Climate Change Education.org (2009) provide resources to all education level teachers and educators to help raise awareness of climate change. This organization is just one example of how environmental education could play a role in the climate change concern, as well as the disconnect with nature in general. 
Studies have shown that environmental education programs can be very beneficial to a child's learning. Observed benefits include better performance on standardized measures of academic achievement in reading, writing, mathematics, and social studies; reduced discipline and classroom management problems; and increased engagement and enthusiasm for learning (Leiberman \& Hoody, 1998). Not only do they benefit children's learning, but can be very beneficial to adults as well. Therefore, it is very important that educators who offer these programs have the most updated and user friendly resources readily accessible through various supporting organizations or agencies. As of 2007, there had never been a needs assessment of environmental educators or programs in West Virginia. The purpose of this study was to conduct a needs assessment of the educators who provide specialized programs in environmental education.

The population for this study was Environmental educators in West Virginia, which included contacts of the West Virginia Environmental Educators Association (WVEEA). In addition to environmental educators, West Virginia Extension Agents were surveyed to determine if County Extension Agents were aware of environmental education programs going on in their county, and if they provided information to environmental educators in their area.

\section{Purpose}

The goal of this study was to create and conduct a needs assessment of educators in the environmental education field in West Virginia. A second goal was to determine if West Virginia County Extension Agents were aware of environmental education programs in their counties, and if so, what role they had in the program. 
After identifying individuals and organizations which provide environmental education programs in West Virginia, a survey was used to gather specific information from the educators. Some of the information collected dealt with what types of programs they provide, to whom and how often. In addition, educators were asked to provide information on their needs for enhancing their programs for the future and to aid in their professional development. Specific questions were asked about their program needs as well as professional development needs. West Virginia County Extension Agents were surveyed separately, in order to assess similar issues of needs and barriers.

\section{Research Questions}

The following broad research questions guided this study:

1. Who are the nonformal environmental educators in West Virginia?

2. What types of programs and services do environmental educators in West Virginia provide?

3. Who is the audience for environmental programs in West Virginia?

4. What are needs of environmental educators in West Virginia?

5. What role do Cooperative Extension Agents play in Environmental Education programs in their counties? 


\section{Chapter 2. Literature Review}

\section{Environmental Education}

Environmental Education has a long history of being a supplemental opportunity for youth - a field trip to the nature center, a week at camp, or a project in the local stream. Even though some would argue that environmental education should be part of national and state standards, it has generally been deemed a topic that is applied to many subjects, not a subject in itself (Monroe, Randall \& Crisp, 2001). Most environmental education is achieved in science classes studying things like the movement of groundwater, but can also be taught in history class discussing the use of natural resources in the development of a new nation, for example. Since environmental literacy means that youth have the awareness, knowledge, ability, motivation, commitment, and skill to work with others to resolve environmental problems and prevent new ones, environmental education activities can also improve communication, group processes, and problem-solving skills to help prepare a society-ready youth (Monroe, Randall \& Crisp, 2001). The United Nations Educational, Scientific and Cultural Organizations (UNESCO) was the first international group to define environmental education, noting it is:

“a learning process that increases people's knowledge and awareness about the environment and associated challenges, develops the necessary skills and expertise to address the challenges, and fosters attitudes, motivations, and commitments to make informed decisions and take responsible action" (1977;1). This definition was set at UNESCO's first conference on environmental education held in Tbilisi, Georgia in 1977. 
The United States Environmental Protection Agency (EPA) states that environmental education does not advocate a particular viewpoint or course of action (U.S. EPA, 2007). Rather, environmental education teaches individuals how to weigh various sides of an issue through critical thinking and enhances their own problem-solving and decision-making skills. Environmental education therefore gives the public the opportunity to increase awareness and knowledge about environmental issues (U.S. EPA, 2007).

The EPA defines the components of environmental education as (1) awareness and sensitivity, (2) knowledge and understanding, (3) attitudes, (4) skills, and (5) participation. The first two components pertain to what a person's awareness, sensitivity, knowledge and understanding are of the environment and the environmental challenges they face. The third component, attitudes, deals with the attitudes of individuals concerning the environment and their motivation to improve or maintain environmental quality. Skills, the fourth component, are needed in order to identify and help resolve environmental challenges. Participation is needed in activities that lead to the resolution of environmental challenges (U.S. EPA, 2007).

Environmental literacy is the primary desired outcome of environmental education programs (U.S. EPA, 2007). Environmental education programs can give people of all ages and backgrounds the opportunity to gain experiences that foster development of the combination of knowledge, skills, and attitudes required to be environmentally literate. Environmental education is a process, and therefore usually does not directly improve the environment, such as air quality. However, environmental education provides people with the capability and skills over time to analyze environmental issues, engage in problem solving, and take action to sustain and improve the environment. In return, this allows individuals to become more capable of weighing various sides of an environmental issue to make informed and responsible decisions 
(U.S. EPA, 2007). This is the process that can potentially lead to improvement of various aspects of the environment.

\section{Formal versus Nonformal Education}

Nonformal education is education that takes place outside the formal school system. It includes programs and activities taking place in museums, nature centers, zoos, aquariums, community clubs, science centers, and other community educational institutions and organizations and also includes television, radio, newspaper, and other media-generated educational programs (Meredith \& Best, 2000).

The term formal education typically refers to the structured educational system provided by the state for children. Formal education systems are usually state-supported and stateoperated, however there are privately funded schools that are also considered to be formal education, such as church schools or other private schools. In contrast, as noted above, nonformal education refers to education which takes place outside of the formally organized school. This education is called nonformal because it is not compulsory, it does not lead to a formal certification, and it may or may not be state-supported (Summer Institute of Linguistics, 1999).

Some of the main differences between formal and nonformal education are (Enhancing Education, 2002):

1. Generally, classrooms in a formal education system have the same kids and same teachers every day, where nonformal after-school programs are often drop-in, so attendance is inconsistent, as is leadership. 
2. Classroom activities can last several days, where after-school programs need to complete an activity each day.

3. Usually, classroom-based teachers have a certain level of training, where after-school program educators could vary in experience and knowledge.

4. Classroom teachers must meet educational standards, where nonformal educators can be more flexible with content.

Both formal and nonformal education settings offer different strengths to educational projects. Classroom projects can have a very long life, but after-school programs offer a different kind of environment where activities don't need to be as formal and can reach a different audience (Enhancing Education, 2002).

\section{Needs Assessment}

A needs assessment is a well-thought out strategy to identify: 1) what one needs to understand, as well as expectations and preferences; 2) a range of reliable, effective and appropriate methods to find this critical information; and 3) ways of building what is learned into all stages of strategic planning and service development (Gardner \& Verrier, 2002). The logic behind identifying educational needs stems from the desire to design and implement relevant educational programs which are based on measurable and achievable goals and objectives (Waters \& Haskell, 1988).

According to Rouda \& Kusy (1995), there are four steps in conducting a needs assessment. The first step is to conduct a "Gap" analysis, which checks the actual performance of organizations against current standards, or to set new standards. For environmental education, we need to determine the current state of skills, knowledge, and ability of our current educators 
and then identify the desired or necessary conditions for the program's success. The latter focuses on the necessary skills, knowledge and abilities needed to accomplish the objectives of environmental education. The difference, or "gap", between the current and necessary should identify a large list of needs (Rouda \& Kusy, 1995).

The second step is to identify the priorities and importance of the needs proposed in step one (Rouda \& Kusy, 1995). The needs should be examined and then importance determined as related to the missions of the various environmental education programs. Step three identifies causes of problems and/or opportunities (Rouda \& Kusy, 1995). After prioritizing the needs identified, the next step is to identify specific problem areas and opportunities in environmental education. Rouda \& Kusy suggest asking two questions for every identified need: Are our educators doing their job effectively? Do they know how to do their job? This requires analysis of educators, their jobs, and their organization - both for the current situation and in preparation for the future.

The final step identifies possible solutions (Rouda \& Kusy, 1995). If the first three steps lead us to believe that environmental educators are doing their jobs effectively, then the potentially best course of action may be to simply provide them opportunities and resources to help them continue. However, if the objectives of environmental education programs are not being met, then training or other resources may be a solution. The first three steps will lead to ideas for satisfying the identified needs.

There have been varieties of methods used to collect information for needs assessments, some of which include advisory committees, survey questionnaires, focus groups, interviews with key informants, or a combination of methods (Caravella, 2006). A report done by Caravella in 2006 describes a method for Extension educators to conduct needs assessments. The method 
included reviewing census data and existing local needs surveys, as well as conducting key informant interviews (Caravella, 2006). Caravella described the steps in the method as: 1) gathering contact information, 2) reviewing recently completed needs assessments, surveys and grant applications, 3) reviewing recent census data, and 4) interviewing key informants. The result is a specific needs assessment that gives a better understanding of what specific topics are needed.

\section{Capacity-building}

A needs assessment can be a crucial step in capacity building for an organization like the WVEEA. Capacity building can be defined as the ability of organizations to fulfill their missions in an effective way (The Urban Institute, 2001). "Capacity" is the knowledge and understanding needed to fulfill a mission, which, for most environmental education programs, is to create comprehensive and sustainable programs (Environmental Education and Training Partnership, 2002). Given this "capacity," communities will work to protect and improve their environment. Education designed to match community interests can increase that capacity. Such community-based education has been widely used to address environmental concerns, among other things (US EPA/Cooperative Extension Partnerships No. 8, 2000). Developing and using an education plan designed to match community interests will help Cooperative Extension and the United States Environmental Protection Agency support community initiatives and enhance community capacity to manage the environment (US EPA/Cooperative Extension Partnerships No. 6, 2000).

Like the WVEEA, many nonprofit organizations are small and have limited resources, so linking capacity with overall performance is critical to strengthening the organization (The 
Urban Institute, 2001). The Urban Institute (2001) believes there are three areas that can help better understand the many facets of capacity building: 1) sustainable development, 2) civil society and social capital, and 3) organizational development and management theory.

Sustainable development encompasses the concepts of balance, time, and place, and focuses on managing the process of change, rather than setting an end goal with fixed outcomes. Balance relates to the tensions and trade-offs in identifying needs, developing strategies to address these needs, and allocating scarce resources. Strategies can be devised for both longand short-term goals. This is important because the time selected will influence the types of approaches that can be taken and the success that can be achieved in different time frames. Because no community is entirely self-sufficient, place and spatial scale are important concepts. Differing spatial scales can create tension among local, regional, and global concerns. Capacity building strategies need to examine both local and larger networks (The Urban Institute, 2001).

Civil society and social capital emphasize the relational aspects of community. Participation in formal and informal organizations builds trust in individuals and institutions. Nonprofit organizations play a critical role by providing a means by which people can interact and work toward common goals. The social capital that is created can be obtained in a variety of ways - volunteers working alongside each other, staff interacting with clients, or board members promoting the organization's activities in the community. Such experiences build ties between people and enhance social capital (The Urban Institute, 2001).

Organizational and management theory emphasizes the operational decisions and tradeoffs that groups face when building their financial and political capacity. Decisions concerning the use of staff, choice of products and services, fundraising and marketing strategies, and even the selection of a board of directors can significantly impact the success or failure of an 
organization. Decision making usually involves foregoing one option in favor of another. Organizational management decisions produce trade-offs that may be either beneficial or detrimental to the short-run or long-term viability of the organization (The Urban Institute, 2001).

Because of the tremendous diversity in the nonprofit sector, the needs and ability of nonprofit organizations to build future capacity will vary widely from one organization to the next. So, determining an organization's capacity-building needs is not a simple or clear-cut process. However, there are five components commonly found in all organizations and intermediary structures: vision and mission, leadership, resources, outreach, and products and services. These five factors are interrelated and mutually dependent on one another. As a system, each factor reinforces the other factors. It is unlikely that all five factors are equally present in any particular organization. Some groups may emphasize one factor over another, but a healthy mix of these five components is necessary for an organization to survive and thrive (The Urban Institute, 2001).

\section{The Role of Extension Agents}

A good resource for capacity building in community organizations are Cooperative Extension Service agents, who are trained professionals that have the responsibility to help improve the quality of life for individuals and families through community education (Koukel \& Cummings, 2002). Early county agents were hired for their practical farm and home experiences. As lifestyles changed, however, the Extension organization has had to adapt to these lifestyle changes in order to meet the demands of society (Russell, 1995). 
Many Extension programs are built upon the parable of teaching people to fish rather than giving them fish. The belief is that the impact will be longer lasting and the clients will be self sufficient if they are taught to fish (Lawrence, Schuknecht \& Lally, 2006). One example of an Extension program that represents this belief is the Livestock Environmental Management System, in which producers were taught how to assess their operation, develop a plan, and implement a systematic approach to address environmental concerns and compliance (Lawrence, Schuknecht \& Lally, 2006).

Because environmental issues are complex, many audiences - farmers, local governmental officials, watershed organizations, and concerned citizens - have questions about rapidly changing environmental policies. Extension has the opportunity to provide timely issuesoriented policy education programs (Dodd \& Abdalla, 2004). For example, in an effort to do just that, Penn State Extension is actively involved in nutrient and water policy education (Dodd \& Abdalla, 2004).

Historically, Extension has focused on providing technical expertise during the policy development process, and Extension specialists trained in soil science, agricultural engineering, and animal production continue to contribute in this role. However, Extension's role has expanded over time to include specialists trained in social sciences, in order to provide public policy information beyond traditional agricultural audiences, which includes environmental issues. In Pennsylvania, there is now one full-time Extension specialists who devotes time to the agricultural environmental public policy programming area (Dodd \& Abdalla, 2004).

Another facet of environmental education, dating back to the early 1900's, that Cooperative Extension is involved in is 4-H horticulture programs. For example, the Virginia Cooperative Extension agents first started working with youth clubs, now known as 4-H clubs, in 
1907, teaching boys to grown corn and girls to grow and can tomatoes. Youth educators using horticulture programs are on the rise today with the awareness that many subject areas can be taught in a dynamic, hands-on way through horticulture (Phibbs, Relf \& Hunnings, 2005). Previous research has shown that children's attitudes toward the environment improved when they were involved in gardening projects (Skelly \& Zajicek, 1998).

\section{Previous Findings from other EE Needs Assessments}

A variety of benefits have been found when schools integrate environmental education into their classrooms. For example, students have been found to learn more effectively within an environment-based context than within a traditional educational framework (Lieberman \& Hoody, 1998). Evidence gathered from 40 schools in a national study conducted by the State Education and Environment Roundtable indicated that when the natural environment is used as an educational setting, students had better performance on tests in reading, writing, math, science and social studies. Students also had less discipline needs in the classroom, higher enthusiasm for learning and a greater pride in their accomplishments (Lieberman \& Hoody, 1998). However, before EE can be taught or integrated into existing schools, curriculums, or programs, a needs assessment should be conducted. Previous needs assessments in EE have been conducted in both formal and nonformal education organizations, yielding useful guidance.

In 2001, a needs assessment was conducted for K-12 teachers in the Northern Kentucky region who were identified as Environmental Education Contacts in their schools (Meichtry, 2001). The study found that of the respondents, the most frequently taught topic was environmental issues, with the topic of environment in general close behind. It also found that the top three needs of these teachers were funding for activities and resources, field trip 
opportunities and curriculum resources. When it comes to training for those surveyed, they felt the biggest training needs were in availability and use of curriculum, technology and development and use of outdoor sites. After the needs assessment was completed, it was shared with other environmental educators in the region, resulting in a collaborative effort between university faculty, $\mathrm{K}-12$ teachers, and nonformal environmental educators in the region to plan and conduct an after-school outdoor classroom workshop for teachers (Meichtry, 2001).

A Washington State Environmental Education needs assessment conducted in 2001-2002 aimed at determining how environmental education could be useful in advancing educational reform and where in-service programs in environmental education might be best directed (Angell, 2002). Ninety-two (92) percent of respondents in the study indicated that the science curriculum is where environmental education was implemented in the formal education setting. Of those responding, 70 percent felt that including environmental education in their instruction was a factor in improving student learning and development, and most respondents wanted more information on how environmental education can help improve student learning. Angell (2002) concluded that even though environmental education is functioning in the school systems, it is still far from achieving the potential level of application in which it is capable of meeting the needs of educators.

A study conducted from 1997 through 1998 reported on the needs of the Pennsylvania Center for Environmental Education (Meredith \& Best, 2000). They sought to collect opinions about perceived needs from current and potential environmental educators (both formal and nonformal) and others who engaged in environmental education teaching activities. Results indicated that a variety of nonformal education organizations provided activities for schools and students, teachers, organized groups and the public. Ninety-two percent of respondents said they 
would be interested in going to workshops with suggested content including networking and standards, practical and easy-to-use ideas, connecting teachers with the public, and education for local officials (Meredith \& Best, 2000).

Another study conducted for the Pennsylvania Center for Environmental Education sought to determine how the Center could effectively serve the diverse needs and interest of environmental education stakeholders in the state (Johnson, 1997). The study found that the highest perceived environmental education need in Pennsylvania was professional development, followed by pre-service education and technical assistance. Almost half of the respondents favored the development of an environmental education resource directory, which would include sources of environmental education material, centers, program availability and resource personnel (Johnson, 1997).

An environmental education needs assessment of schools located in an urban watershed found that inadequate educator knowledge of environmental issues, lack of state proficiency standards for environmental education, and lack of funding for environmental projects are barriers hampering the achievement of environmental education objectives (Wood-Arendt, 2003). Respondents to the Hunting Creek Watershed Environmental Education Needs Questionnaire desired greater knowledge of science-based resources for teaching environmental education (Wood-Arendt, 2003).

In 2001, a study was conducted by the Environmental Education and Training Partnership on training needs of a variety of different state coordinators of environmental education programs. The respondents indicated the largest need was in the areas of finances and fundraising. Over one-quarter of the respondents stated that they were limited in training by the amount of resources available. Other areas of training interest included marketing, instructional 
techniques, education standards, program assessment, and communication methods (Environmental Education \& Training Partnership, 2002).

Based on the many studies done concerning environmental education programs, the biggest barriers to providing quality education in the programs are lack of training, funding, and inadequate educator knowledge and training. These barriers lead to needs of curriculum resources, funding for activities and resources and professional development opportunities. Many noted that they would like to see professional development opportunities in the areas of use of curriculum, technology, marketing, networking and easy to use ideas. A combination of many of these needs could help improve environmental education program learning. 


\section{Chapter 3. Methodology}

The purpose of this study was to identify those individuals and organizations that provide environmental education to audiences in West Virginia, and conduct a needs assessment of those organizations. The objectives were to gather specific information on what types of programs these educators provide, and what needs they might have to improve their programs.

\section{Research Questions}

The following broad research questions guided this study:

1. Who are the nonformal environmental educators in West Virginia?

2. What types of programs and services do environmental educators in West Virginia provide?

3. Who is the audience for environmental programs in West Virginia?

4. What are needs of environmental educators in West Virginia?

5. What role do Cooperative Extension Agents play in Environmental Education programs in their counties?

\section{Population}

Two different groups of educators comprised the target population for this study. The population consisted of 92 contacts of the WVEEA and 102 County Extension Agents. The contacts of the WVEEA are all formal or nonformal environmental educators, which include educators from organizations, government and schools across the state. Every county in West Virginia has at least one Extension Agent, and surveys were sent to each Extension Agent in every County Office. These agents have a variety of jobs, including agriculture, youth 
development and education. A census was attempted with both groups, because the populations were fairly small in number.

\section{Study Area}

West Virginia is located close to the east coast, and is bordered by Maryland, Pennsylvania, Ohio, Kentucky and Virginia. West Virginia is known as the "Mountain State" for the Appalachian Mountains that run through almost the entire state. West Virginia's spectacular mountains, swirling rivers, and scenic countryside make it the perfect place to educate youth and adults on the environment. The state is also home to more than 200,000 acres of state parks, forests and wildlife management areas where natural wonder is preserved (WV Wild and Wonderful, 2008).

\section{Data Collection Procedures}

This study was applied research, rather than basic research (i.e., the testing of theoretical models) (Graziano \& Raulin, 1997). Applied research is designed to solve practical problems rather than to acquire knowledge for knowledge's sake like basic research. One might say that the goal of the applied scientist is to improve the human condition (Lawrence Berkeley National Laboratory, 2008).

The assessment methodology used to collect data was a mailed questionnaire with both closed and open-ended questions. The questionnaires were completed during August and September of 2008. Questionnaires were mailed to all participants accompanied by a cover letter that stated the objectives of the survey. Using a modified Total Design method (Dillman, 2007), after 10 days an email reminder was sent. Two weeks following that reminder, another email 
reminder and another hard copy of the survey was sent to those that had not yet returned the survey.

\section{Instrumentation}

All contacts of the WVEEA and all West Virginia Extension Agents were asked to complete a mailed questionnaire. The survey was estimated to take approximately 10 minutes to complete. Addresses for WVEEA contacts were obtained from a database of that was created at the March 2008 state WVEEA conference. Surveys for the Extension Agents were sent to all 55 County Extension offices for each extension agent $(\mathrm{N}=102)$ employed during August and September of 2008 .

The surveys for each group were different, but included questions that addressed program demographics, resource and professional development needs and current program curriculum. Many of the questions included in this survey were adapted from a similar study done in Alberta, Canada (ACEE, 2006). Some of the questions on both of the surveys were created specifically for the groups that were surveying.

The WVEEA survey was pilot tested in July of 2008. The WVEEA board of directors was asked to complete a draft of the survey prior to the completion and mailing of the final survey. This was done to receive suggestions for improvements, question clarification, as well as an estimated completion time for the survey. 


\section{Delimitations}

The target group for the research consists only of known WVEEA contacts and West Virginia University County Extension Agents. Because of this, the survey may not have reached all environmental educators and facilitators in West Virginia.

\section{Limitations}

The survey only reflected self-reported perceptions of prospective members of the WVEEA and West Virginia University County Extension Service. The results do not necessarily reflect the opinions of all environmental educators in West Virginia. 


\section{Chapter 4. Results}

A total of 92 surveys were sent to contacts associated with the West Virginia Environmental Education Association (WVEEA) in August and September, 2008. Of the 92, 46 responded, with a $50 \%$ response rate. The mean age of the respondents was $44,63 \%$ were female and $37 \%$ were male. The majority of respondents were Caucasian (91\%) and many had completed a graduate degree $(44 \%)$.

In August and September, 2008, 102 surveys were sent out to Extension Agents in West Virginia. Of 102, 41 responded, with a $40 \%$ response rate. The mean age of the respondents was $44,56 \%$ were female while $44 \%$ were male. The majority of respondents were Caucasian (97\%) and had completed a graduate degree (95\%).

\section{Environmental Education Program Description}

The WVEEA respondents were mostly associated with a non-profit organization (44\%), such as The Friends of Deckers Creek; a government agency (33\%), such as the National Park Service; or a university or college (11\%), such as West Virginia University (see Table 4.1). Of the 44 percent that were associated with a non-profit organization, 91 percent were an incorporated non-profit in West Virginia, of which all but one have a charitable status. Fortyone percent of the non-profit respondents said they had members in their organizations. The median number of members in these organizations was 362 members. Approximately 26\% (6) of the non-profit organizations had large memberships in excess of 900 members. The number of members in the non-profit organizations ranged from zero to 40,000, and the mean number of 
members was 3,110. Therefore, the median of 362 was used, giving a more accurate representation of the membership numbers of the organizations.

Table 4.1.

\begin{tabular}{ll} 
EE Organization Category & $\begin{array}{l}\text { Number (Percentage) } \\
\text { Ny=46) }\end{array}$ \\
\hline Non-Profit Organization & $20(44 \%)$ \\
Government Agency & $15(33 \%)$ \\
University or College & $5(11 \%)$ \\
Public School K-12 & $4(9 \%)$ \\
Private For-Profit Group & $1(2 \%)$ \\
Funder & $1(2 \%)$ \\
Private School K-12 & $0(0 \%)$ \\
\hline
\end{tabular}

Some of the most commonly mentioned environmental issues/topics that the respondents' programs addressed were water, plant life, wildlife and ecosystems (see Table 4.2). There were a few "other" topics that several respondents wrote in, including forestry, general environmental issues and education. 
Table 4.2 .

Environmental Issues Addressed by Programs

\begin{tabular}{ll}
\hline Environmental Issues & $\begin{array}{l}\text { Number (Percentage) } \\
(\mathrm{N}=47)\end{array}$ \\
\hline Water (water quality, watersheds, water cycle, etc) & $40(85 \%)$ \\
Ecosystems/habitats & $29(62 \%)$ \\
Plant Life & $27(57 \%)$ \\
Wildlife & $27(57 \%)$ \\
Global Warming & $20(43 \%)$ \\
Air Quality & $19(40 \%)$ \\
Energy & $17(36 \%)$ \\
Other & $13(28 \%)$
\end{tabular}

The most common type of environmental education programs offered by respondents included school programs (72\%), special events (70\%), children's programs (57\%) and adult programs (55\%) (See Table 4.3). Several other respondents (32\%) indicated that they provide trainings for facilitators and teachers, and do outdoor classrooms. Seventy-two percent of the respondents said their programs are conducted year round, while only $11 \%$ were conducted seasonally. Many others (19\%) noted that they provided programs upon request and as funding allowed. Twenty-seven percent of respondents said their programs are conducted two to six times per year, and $22 \%$ said they conduct their programs at least once per month (see Table 4.4). 
Table 4.3.

Type of EE Programs Offered

\begin{tabular}{ll}
\hline Program & $\begin{array}{l}\text { Number (Percentage) } \\
(\mathrm{N}=47)\end{array}$ \\
\hline In School activities & $34(72 \%)$ \\
Special Events & $33(70 \%)$ \\
Children's Programs & $27(57 \%)$ \\
Adult Programs & $26(55 \%)$ \\
Day Camps & $16(34 \%)$ \\
Web Based & $9(19 \%)$ \\
Residential Camps & $8(17 \%)$ \\
Other & $15(32 \%)$ \\
\hline
\end{tabular}

Table 4.4.

EE Programs Conducted per Year

\begin{tabular}{ll}
\hline How often & $\begin{array}{l}\text { Number (Percentage) } \\
(\mathrm{N}=45)\end{array}$ \\
\hline 2-6 per year & $12(27 \%)$ \\
At least one per month & $10(22 \%)$ \\
Daily & $8(18 \%)$ \\
2-3 times per month & $7(16 \%)$ \\
At least one per week & $3(7 \%)$ \\
One per year & $0(0 \%)$ \\
2-3 times per week & $0(0 \%)$ \\
Other & $5(11 \%)$ \\
\hline
\end{tabular}


When asked about their annual program participation, the most reported ranges were between 1001 and 5000 participants (27\%) and between 251 and 500 participants (20\%) (see Table 4.5). Fifty-five percent of respondents did conduct teacher trainings. Of those conducting teacher trainings, the mean number of teachers trained last year was 109. Respondents were also asked what areas of existing West Virginia curriculum their programs currently addressed. The most commonly addressed curriculum was junior high science (70\%), elementary science (61\%) and high school biology (54\%) (see Table 4.6). Thirty percent of respondents noted "other" areas of curriculum they addressed. These included providing teacher trainings/service learning, pre-school, art and earth/environmental science.

Table 4.5.

\begin{tabular}{ll} 
Program Participants & $\begin{array}{l}\text { Number (Percentage) } \\
\text { (N=45) }\end{array}$ \\
\hline Participants & $9(20 \%)$ \\
$101-250$ & $5(11 \%)$ \\
$251-500$ & $9(20 \%)$ \\
$501-1000$ & $3(7 \%)$ \\
$1001-5000$ & $12(27 \%)$ \\
Over 5000 & $7(16 \%)$ \\
\hline
\end{tabular}


Table 4.6.

WV Curriculum Addressed

\begin{tabular}{ll}
\hline Curriculum & $\begin{array}{l}\text { Number (Percentage) } \\
(\mathrm{N}=43)\end{array}$ \\
\hline Jr. High Science & $30(70 \%)$ \\
Elementary Science & $26(61 \%)$ \\
High School Biology & $13(30 \%)$ \\
Elementary Social Studies & $12(28 \%)$ \\
High School Chemistry & $11(26 \%)$ \\
Jr. High Social Studies & $11(26 \%)$ \\
High School Social Studies & $10(23 \%)$ \\
High School Agri-Science & $7(16 \%)$ \\
High School Physics & $13(30 \%)$ \\
Other &
\end{tabular}

When asked about the demand for their environmental education programs, $56 \%$ of respondents said the demand for their programs were increasing, while 38\% said demand was staying the same and only six percent said demand was decreasing. Respondents said that they were able to meet the demands of their programs "very often" $(47 \%)$ while some said they were only "sometimes" able to meet the demand for their programs (36\%). The respondents were also asked about their organization's annual operating budget. It appears that most organizations either have a fairly small budget of less than $\$ 20,000(29 \%)$ or a fairly large budget of over $\$ 250,000$ (24\%) (See Table 4.7). In addition, nearly 20\% indicated that the annual operating budget was not applicable to them. Most of these respondents were associated with a government agency, education in universities or public schools. 
Table 4.7.

\begin{tabular}{ll} 
Annual Operating Budget & $\begin{array}{l}\text { Number (Percentage) } \\
(\mathrm{N}=42)\end{array}$ \\
\hline Budget & $5(12 \%)$ \\
\hline Under $\$ 5,000$ & $7(17 \%)$ \\
$\$ 5,000-20,000$ & $1(2 \%)$ \\
$\$ 20,000-50,000$ & $4(10 \%)$ \\
$\$ 50,000-100,000$ & $1(2 \%)$ \\
$\$ 100,000-150,000$ & $6(14 \%)$ \\
Over $\$ 250,000$ & $10(24 \%)$ \\
Not Applicable & $8(19 \%)$ \\
\hline
\end{tabular}

Seventy percent of the respondents reported that they have full time staff members, and of those, the median number of staff is two. Forty-one percent of respondents reported they have part-time staff members, and of those, the median number is two. Forty-four percent of respondents said they have volunteer staff members, and of those, the median number is eight.

\section{Extension Agents' Knowledge of EE in County}

Sixty-three percent of the Extension Agents who responded to the survey were aware of Environmental Education Programs that were being conducted in their respective counties. Some of the most commonly reported programs were farm related programs $(50 \%)$, recycling (46\%), 4-H programs and camps (35\%), and Farm horticulture programs (15\%) (see Table 4.8). Sixty-seven percent of the respondents said their county Extension Offices do provide materials for these programs. The materials they provide come from various places, but most of the 
resources come from West Virginia University Extension Service (50\%), the Department of Agriculture (23\%) and the Internet (15\%) (see Table 4.9).

Table 4.8 .

\begin{tabular}{ll} 
Awareness of EE in County & $\begin{array}{l}\text { Number (Percentage) } \\
(\mathrm{N}=26)\end{array}$ \\
\hline EE Programs & $13(50 \%)$ \\
\hline FFA/Farm Related Programs & $12(46 \%)$ \\
Recycling & $9(35 \%)$ \\
4-H Programs & $4(15 \%)$ \\
Horticulture & $4(15 \%)$ \\
Conservation & $4(15 \%)$ \\
Private Organizations & $3(12 \%)$ \\
Enviro-thon & $3(12 \%)$ \\
Watershed Projects & $1(4 \%)$ \\
County Fair &
\end{tabular}


Table 4.9.

Materials Provided to County EE Programs

\begin{tabular}{ll} 
Material Source & $\begin{array}{l}\text { Number (Percentage) } \\
(\mathrm{N}=26)\end{array}$ \\
\hline Extension Service & $16(62 \%)$ \\
Department of Agriculture & $6(23 \%)$ \\
Internet & $4(15 \%)$ \\
Solid Waste Authority & $3(12 \%)$ \\
4-H Project Books & $3(12 \%)$ \\
Conservation Groups & $2(8 \%)$ \\
Department of Environmental Protection & $2(8 \%)$ \\
Other & $6(23 \%)$
\end{tabular}

Barriers \& Opportunities-Comparing the EE and Extension respondents

The WVEEA survey respondents were given a list of barriers that they might have encountered in their work in environmental education. They were asked to indicate how significant the barrier was to their work on a scale of 1-4, with 1 being "Not Significant" and 4 being "Very Significant." The barriers reported as "very significant" were "teachers lack of time to fully participate in programs" (39\%), and "escalating busing costs" (34\%) (see Table 4.10). In addition, other "significant" barriers noted by many included "partnership creation being difficult and time consuming" (43\%) and "not knowing what other organizations are up to" $(36 \%)$. Barriers that were suggested as being "a little significant" were "lack of evaluation tools to measure effectiveness and improve programs" (48\%), “concerns over liability vis-à-vis outdoor programs" (44\%) and "lack of support within my organization" (43\%). Some of the barriers that 
they noted as "not significant" were "difficulty keeping staff" (61\%), "lack of curriculum fit" (59\%) and "not hearing about professional development opportunities" (51\%). See Table 4.10 for a complete list of rankings of barriers environmental educators in West Virginia face.

The Extension Agents were given the same list of barriers, and asked to indicate their significance using the same scale noted above (1-4). The barriers noted as "very significant" by this group of respondents were "lack of time to plan, develop or update programs" (49\%), "teachers lack time to fully participate in programs" (47\%), and "lack of funding for programs" (44\%) (see Table 4.10). Barriers that were suggested as being "significant" were "teachers lack of time to fully participate in programs" (56\%), "low demand from key audiences" (56\%) and "difficulty contacting and/or engaging new audiences (51\%). Extension Agents indicated many barriers that were "a little significant" to their work, such as "lack of support within my organization" (46\%), "poor understanding of how to define/implement excellent environmental education" (46\%), "concerns over liability vis-à-vis outdoor programs" (43\%) and "lack of evaluation tools to measure effectiveness and improve programs" (43\%). Several of the barriers that were indicated to be "not significant" to this group were "difficulty keeping staff" $(33 \%)$, "lack of support within their organization" (29\%) and "staff burnout" (21\%) (although 38\% reported that volunteer burnout was a barrier). 
Table 4.10.

Program Barriers

Barriers N(\%)

$\mathrm{N}=43$ (WVEEA)

$\mathrm{N}=35$ (Ext.)

a. Difficulty

contacting and or engaging new audiences

b. Teachers lack time to fully participate in programs

c. Teachers lack interest to fully participate in programs

d. Inadequate background knowledge by teachers

e. Concerns over liability vis-à-vis outdoor programs

f. Escalating busing costs means fewer site visits

g. Lack of time to plan, develop or update programs

h. Lack of evaluation tools to measure effectiveness and improve programs

i. Partnership creation takes time and is difficult

j. Lack of curriculum fit

k. Difficulty keeping staff

1. Lack of relevant professional development for

\begin{tabular}{cccccccc}
\multicolumn{2}{c}{$\begin{array}{c}\text { Very } \\
\text { Significant }\end{array}$} & \multicolumn{2}{c}{ Significant } & \multicolumn{2}{c}{$\begin{array}{c}\text { A Little } \\
\text { Significant }\end{array}$} & \multicolumn{2}{c}{$\begin{array}{c}\text { Not } \\
\text { Significant }\end{array}$} \\
\hline WVEEA & Ext. & WVEEA & Ext. & WVEEA & Ext. & WVEEA & Ext. \\
12 & 9 & 21 & 51 & 40 & 37 & 28 &
\end{tabular}

39

47

32

39

18

11

11

3

$\begin{array}{llllllll}12 & 22 & 33 & 56 & 28 & 17 & 28 & 6\end{array}$

\begin{tabular}{|c|c|c|c|c|c|c|c|}
\hline 9 & 20 & 30 & 37 & 40 & 26 & 21 & 17 \\
\hline 9 & 20 & 14 & 29 & 44 & 43 & 33 & 9 \\
\hline 34 & 43 & 41 & 34 & 16 & 20 & 9 & 3 \\
\hline 11 & 49 & 32 & 34 & 41 & 17 & 16 & 0 \\
\hline 9 & 20 & 27 & 34 & 48 & 43 & 16 & 3 \\
\hline 5 & 20 & 43 & 46 & 39 & 29 & 14 & 6 \\
\hline 0 & 14 & 16 & 39 & 25 & 39 & 59 & 8 \\
\hline 5 & 6 & 14 & 24 & 21 & 36 & 61 & 33 \\
\hline 7 & 11 & 11 & 37 & 36 & 34 & 47 & 17 \\
\hline
\end{tabular}




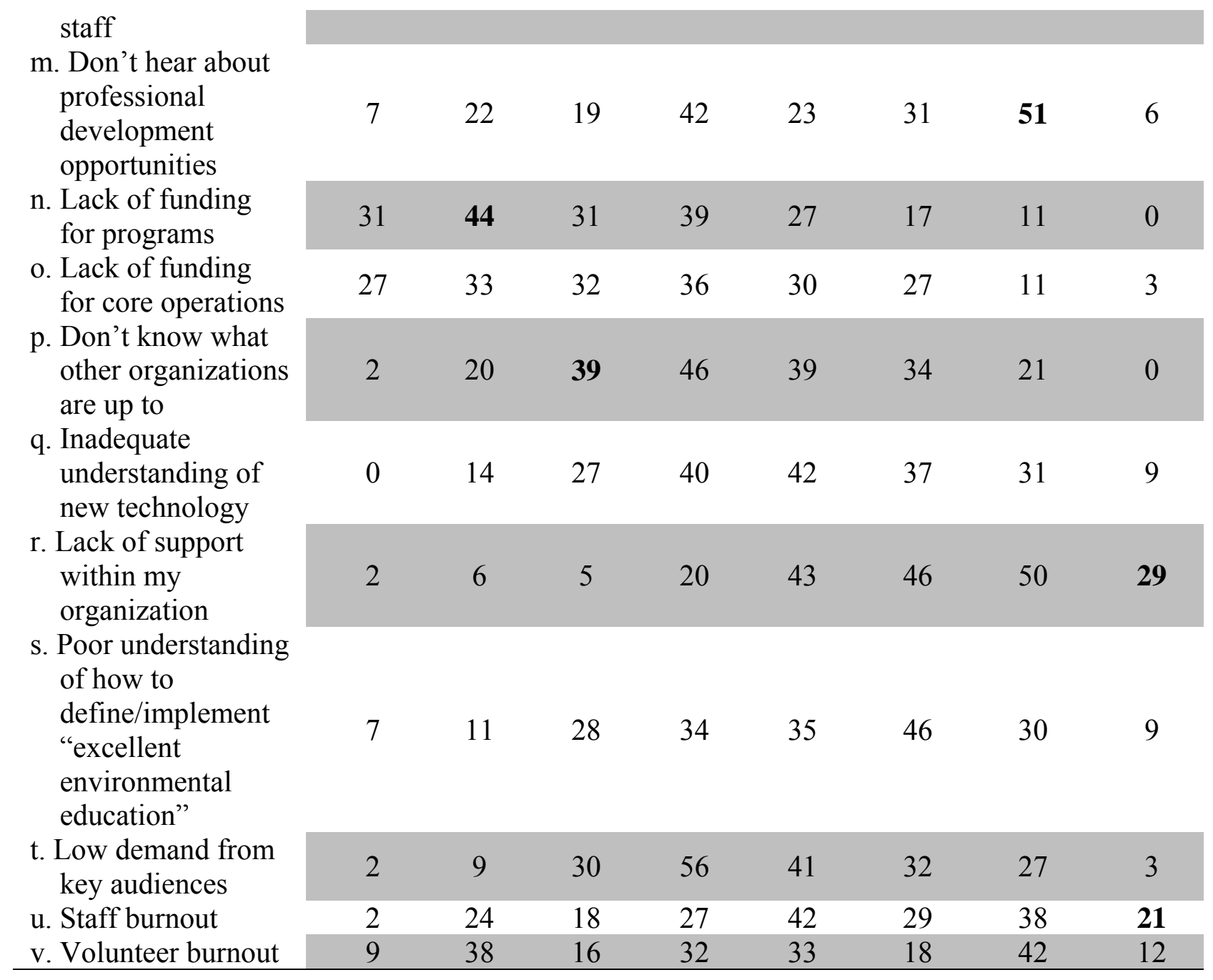

The WVEEA group was given a list of several topics that the WVEEA could potentially help provide professional development programs for environmental education providers. They were asked to indicate how valuable the topic would be to them and their programs on a scale of 1-4, with 1 being "Not Valuable" and 4 being "Very Valuable." Those professional development opportunities that were reported to be "very valuable" were "moving from ideas to action" (44\%) and "how to improve your program based on current research and what is known about environmental education" (36\%) (see Table 4.11). A high percentage of respondents also felt that the topics of "the NAAEE guidelines for excellence in environmental education" (53\%), 
"how to reach and broaden your audience" (52\%) and "how to design teaching resources" (49\%) would all be "valuable" professional development topics. Opportunities that were suggested to be "a little valuable" were "how to find quality, current research on environmental issues" (36\%) and "how to maintain a successful outdoor education program" (30\%). Professional development opportunities that were seen as "not valuable" were "how to provide and deliver effective teacher training workshops" (13\%) and "youth engagement" (11\%) See Table 4.11 for a complete analysis of professional development ideas for environmental education providers.

The Extension Agents were given the same list of topics regarding professional development opportunities for their counties. The agents were asked to indicate how valuable the topic would be to them and their county on the same scale of $1-4$. The most commonly noted professional development opportunities that were considered "very valuable" were "youth engagement" (49\%) and "how to maintain a successful outdoor education program" (40\%) (see Table 4.11). Respondents felt that the topics of "how to improve your program based on current research and what is known about environmental education" (65\%), "how to provide and deliver effective teacher training workshops" (62\%) and "how to reach and broaden your audience" (62\%) would all be "valuable" professional development topics as well. Opportunities that were suggested to be "a little valuable" were "how to design teaching resources" (24\%) and "how to find quality, current research on environmental issues" (24\%). There were only two topics that the Extension Agents reported as being "not valuable." These were "how to evaluate the success of your environmental education program" (3\%) and "the NAAEE guidelines for excellence in environmental education: how to use them and how to adapt them to WV" $(3 \%)$. 
Table 4.11.

Professional Development Opportunities

\begin{tabular}{|c|c|c|c|c|c|c|c|c|}
\hline \multirow{2}{*}{$\begin{array}{l}\text { Opportunities (\%) } \\
\mathrm{N}=44 \text { (WVEEA) } \\
\mathrm{N}=37 \text { (Ext.) }\end{array}$} & \multicolumn{2}{|c|}{ Very Valuable } & \multicolumn{2}{|c|}{ Valuable } & \multicolumn{2}{|c|}{$\begin{array}{l}\text { A Little } \\
\text { Valuable }\end{array}$} & \multicolumn{2}{|c|}{ Not Valuable } \\
\hline & $\begin{array}{c}\text { WVEE } \\
\text { A }\end{array}$ & Ext. & $\begin{array}{c}\text { WVEE } \\
\text { A }\end{array}$ & Ext. & $\begin{array}{c}\text { WVEE } \\
\text { A }\end{array}$ & Ext. & $\begin{array}{c}\text { WVEE } \\
\text { A }\end{array}$ & Ext \\
\hline $\begin{array}{l}\text { a. How to improve your } \\
\text { program, based on current } \\
\text { research and "what is } \\
\text { known" about } \\
\text { environmental education }\end{array}$ & 36 & 24 & 32 & 65 & 32 & 11 & 0 & 0 \\
\hline
\end{tabular}

b. Moving from ideas to actions: how to optimize your program to maximize environmentally

$\begin{array}{llllllll}44 & 22 & 36 & 60 & 18 & 19 & 2 & 0\end{array}$
responsible behavior

c. How to evaluate the success of your environmental education

27 program

d. The NAAEE guidelines for excellence in environmental education: how to use them, how to adapt them to WV

e. Youth engagement: how to communicate with youth and engage them in your program and in your planning

f. How to maintain a successful outdoor education program

$\begin{array}{llll}20 & 5 & 53 & 57\end{array}$

22

$35 \quad 4$

g. Curriculum review: work to make changes to emerging or existing 26

26

49

39

32

24

19

11

0 curriculum

h. How to provide and deliver effective teacher training workshops

i. How to design teaching resources (i.e., activity book, multi-media, etc.)

j. How to reach and broaden your audience

$\begin{array}{llll}26 & \mathbf{4 0} & 39 & 53 \\ 24 & 24 & 47 & 57\end{array}$

30

8

$4 \quad 0$

$22 \quad 16 \quad 46$

62

20

19

$19 \quad 7 \quad 0$


Respondents were asked if they would be willing to provide a professional development session or informal gathering in any of these, or other, areas of interest. Forty-three percent of the WVEEA respondents answered "yes" that they would be willing to provide training. Of those, respondents felt they were knowledgeable enough to provide a session in youth engagement, program evaluations, "No Child Left Inside" or outdoor learning, and teacher/educator workshops.

\section{WVEEA Organizational Needs}

The WVEEA individuals completing the survey were asked about their organizational development needs. In order to help improve organizational capacity, respondents were asked what priority they would place on a list of potential development opportunities. The opportunities with the ranking of "high priority" to the respondents were "project/program planning and development" (44\%) and "grant application and proposal writing" (44\%). Those needs with "medium priority" were "evaluating success" (52\%) and "strategic planning" (51\%). The opportunities ranked "low priority" were "governance and leadership" (54\%), "human resources" (45\%), "staff retention" (42\%) and "financial management" (41\%) (See Table 4.12). 
Table 4.12.

Capacity Building Training Needs

\begin{tabular}{|c|c|c|c|c|}
\hline $\begin{array}{l}\text { Training Needs } N(\%) \\
(\mathrm{N}=43)\end{array}$ & $\begin{array}{l}\text { High } \\
\text { Priority }\end{array}$ & $\begin{array}{l}\text { Medium } \\
\text { Priority }\end{array}$ & $\begin{array}{l}\text { Low } \\
\text { Priority }\end{array}$ & $\begin{array}{c}\text { Not } \\
\text { Applicable }\end{array}$ \\
\hline Governance and/or leadership & $5(12)$ & $11(26)$ & $23(54)$ & $4(9)$ \\
\hline Board/leadership development & $6(14)$ & $18(42)$ & $15(35)$ & $4(9)$ \\
\hline Strategic planning & $13(30)$ & $22(51)$ & $6(14)$ & $2(5)$ \\
\hline $\begin{array}{l}\text { Project/program planning and/or } \\
\text { development }\end{array}$ & $19(44)$ & $12(28)$ & $10(23)$ & $2(5)$ \\
\hline Project management & $13(30)$ & $18(42)$ & $9(21)$ & $3(7)$ \\
\hline Financial management & $3(7)$ & $19(43)$ & $18(41)$ & $4(9)$ \\
\hline General fundraising & $14(32)$ & $15(34)$ & $8(18)$ & $7(16)$ \\
\hline $\begin{array}{l}\text { Grant application and/or } \\
\text { proposal writing }\end{array}$ & $19(44)$ & $15(35)$ & $6(14)$ & $3(7)$ \\
\hline Organizational promotion & $13(30)$ & $21(49)$ & $5(12)$ & $4(9)$ \\
\hline General communications & $9(21)$ & $20(48)$ & $11(26)$ & $2(5)$ \\
\hline Volunteer recruitment & $10(23)$ & $13(30)$ & $13(30)$ & $8(18)$ \\
\hline Volunteer management & $9(21)$ & $12(28)$ & $14(33)$ & $8(19)$ \\
\hline Evaluating success & $11(26)$ & $22(52)$ & $7(17)$ & $2(5)$ \\
\hline Human resources & $3(7)$ & $13(31)$ & $19(45)$ & $7(17)$ \\
\hline Staff retention & $4(9)$ & $8(19)$ & $18(42)$ & $13(30)$ \\
\hline $\begin{array}{l}\text { Collaboration with like-minded } \\
\text { colleagues }\end{array}$ & $14(32)$ & $18(41)$ & $10(23)$ & $2(5)$ \\
\hline $\begin{array}{l}\text { Collaboration with non- } \\
\text { traditional partners }\end{array}$ & $15(35)$ & $17(40)$ & $9(21)$ & $2(5)$ \\
\hline
\end{tabular}

The respondents were given a list of sources of information and asked to rank how important each was for their organization. Each source of information was ranked on a scale of 
1-4, with one being "not important" and 4 being "very important." The sources that were indicated to be "very important" were "personal contact with experts" (52\%), "scientific studies and research" (46\%) and "network meetings with colleagues" (43\%) (See Table 4.13). Some of the other sources of information that respondents felt were "important" were "electronic newsletters" (53\%), “attending conferences" (51\%), “training workshops” (51\%) and "electronic media" (50\%). Sources of information that were reported as being "a little important" were "County Extension Service \& Agents" (50\%), "web or video conferencing" (50\%) and "paper newsletters" (49\%). Sources noted as "not important" were "paper newsletters" (14\%), “telephone conferencing” (14\%) and "County Extension Service \& Agents” (12\%). 
Table 4.13.

\begin{tabular}{|c|c|c|c|c|}
\hline $\begin{array}{l}\text { Information Sources } \mathrm{N}(\%) \\
(\mathrm{N}=45)\end{array}$ & $\begin{array}{c}\text { Very } \\
\text { Important } \\
\end{array}$ & Important & $\begin{array}{l}\text { A Little } \\
\text { important }\end{array}$ & $\begin{array}{c}\text { Not } \\
\text { important }\end{array}$ \\
\hline Attending conferences & $16(36)$ & $23(51)$ & $5(11)$ & $1(2)$ \\
\hline Training workshops & $18(40)$ & $23(51)$ & $3(7)$ & $1(2)$ \\
\hline Email list serves & $11(24)$ & 22 (49) & $12(27)$ & $0(0)$ \\
\hline Electronic newsletters & $8(18)$ & $24(53)$ & $13(29)$ & $0(0)$ \\
\hline Paper newsletters & $4(9)$ & $12(28)$ & $21(49)$ & $6(14)$ \\
\hline County Extension Service \& Agents & $3(7)$ & $12(31)$ & $21(50)$ & $6(12)$ \\
\hline Conducting internet research & $17(38)$ & $14(31)$ & $11(24)$ & $3(7)$ \\
\hline Scientific studies and/or research & $20(46)$ & $14(32)$ & $8(18)$ & $2(5)$ \\
\hline Mainstream print & $2(4)$ & $22(49)$ & $15(33)$ & $6(13)$ \\
\hline $\begin{array}{l}\text { Electronic media (web pages; blogs, } \\
\text { etc.) }\end{array}$ & $13(30)$ & $22(50)$ & $8(18)$ & $1(2)$ \\
\hline Specialty newsletters and periodicals & $9(21)$ & $14(33)$ & $15(36)$ & $4(10)$ \\
\hline Personal contact with experts & $23(52)$ & $21(48)$ & $0(0)$ & $0(0)$ \\
\hline Web or video conferencing & $6(14)$ & $12(27)$ & $22(50)$ & $4(9)$ \\
\hline Telephone conferencing & $5(11)$ & $23(52)$ & $10(23)$ & $6(14)$ \\
\hline Network meetings with colleagues & 19 (43) & $19(43)$ & $5(11)$ & $1(2)$ \\
\hline
\end{tabular}

Those completing the survey were asked a few questions that will be used to help guide strategic planning for the WVEEA. Respondents were asked what they felt WVEEA's role should be. Each was given five potential roles for the WVEEA and asked to rank each from 1-5, with one being the most important role. The number one role reported by respondents was to 
facilitate leadership, followed by connect to the wider EE community, increase capacity, build state networks and champion environmental education (see Table 4.14).

Table 4.14.

WVEEA's Role

\begin{tabular}{lc}
\hline Role & $\begin{array}{c}\text { Rank } \\
(\mathrm{N}=44)\end{array}$ \\
\hline $\begin{array}{l}\text { Facilitate leadership. WVEEA will help develop and coordinate } \\
\text { leadership within the West Virginia EE community. }\end{array}$ & 1
\end{tabular}

Connect to the wider EE community. WVEEA will work with all interested EE providers to promote resources, services, and events to the widest possible audience of WV educators, and connect our efforts to relevant national initiatives.

Increase capacity. WVEEA will develop partnerships and mechanisms to build capacity for, and help ensure, the continual improvement of EE groups. WVEEA will provide professional development opportunities to a variety of EE providers.

Build state networks. WVEEA will develop, encourage and support a 4 statewide network of environmental education professionals that help the exchange of information and provide for collaborative opportunities within the EE community.

Champion environmental education. WVEEA should be a voice for the advancement of EE.

The WVEEA contact list was asked who they thought should comprise the primary membership base of the organization. Of those that responded to this open-ended question, 54\% felt that teachers and educators should be the main membership base. In addition, any individual or organization providing environmental education (31\%) and agency workers $(21 \%)$ were perceived to be a part of the potential membership base for the WVEEA (see Table 4.15). 
Table 4.15.

Membership Base for WVEEA

\begin{tabular}{ll}
\hline Members & $\begin{array}{l}\text { Number (Percentage) } \\
(\mathrm{N}=39)\end{array}$ \\
\hline Educators/Teachers & $21(54 \%)$ \\
Organizations/Individual providing EE & $12(31 \%)$ \\
Agency workers & $8(21 \%)$ \\
Formal \& Nonformal EE providers & $7(18 \%)$ \\
Individuals & $7(18 \%)$ \\
Education organizational & $5(13 \%)$ \\
leaders/administration & $2(5 \%)$ \\
Business Representatives & $2(5 \%)$ \\
NGO's & $2(5 \%)$ \\
West Virginia University & $1(3 \%)$ \\
Non-traditional organizations & $1(3 \%)$ \\
Non-profit camps & $1(3 \%)$ \\
Industry Experts & $1(3 \%)$
\end{tabular}

Those participating in the survey were asked what they expected to receive from WVEEA if they chose to join. Those that responded to the question reported they would like to receive networking opportunities $(66 \%)$, professional development opportunities $(28 \%)$ and felt they would gain resources $(20 \%)$ by joining the organization (See Table 4.16$)$. 
Table 4.16.

Benefits of joining WVEEA

Benefit

Number (Percentage)

$(\mathrm{N}=35)$

Networking

$23(66 \%)$

Professional Development

$10(29 \%)$

Resources

$7(20 \%)$

State wide recognition of EE

$5(14 \%)$

Curriculum/information

$5(14 \%)$

Annual conference

$5(14 \%)$

Ideas

$4(11 \%)$

Support \& Partnership

$3(9 \%)$

Listserv/newsletters

$3(9 \%)$

Committees to work with the WV Department of Ed

$1(3 \%)$

WVEEA to help pay travel expense

$1(3 \%)$

Counter industry EE propaganda

$1(3 \%)$

Membership Patch

$1(3 \%)$

EE legislation updates

$1(3 \%)$

Audience \& volunteers

$1(3 \%)$ 


\section{Chapter 5. Discussion}

The results of this study have important implications for environmental education programs in West Virginia as well as the West Virginia Environmental Education Association that has recently been created in the state. Being able to understand the needs of environmental educators and their programs across the state can provide a direction for the WVEEA and help focus their efforts. For instance, many respondents of the survey said they expected to have networking opportunities available to members of the organization, therefore the WVEEA should work toward a goal of providing networking opportunities.

In addition to supporting environmental educators, the WVEEA has the potential to help West Virginia Extension Agents become a better source of information for their county's environmental education programs. Most extension agents that were surveyed knew of environmental education programs that were being conducted in their respective counties, but would have liked to have more current, up to date information to supply to the program providers.

These two different groups of people - WVU Extension Agents and WVEEA contacts were asked the same questions concerning barriers that face their programs. There were several differences as well as similarities among their responses. Some interesting differences between the two groups were found in regards to the significance of certain barriers. For example, more WVEEA contacts felt that "lack of curriculum fit" was not a significant barrier to their environmental education programs compared to the extension agents. Extension agents were more likely than the WVEAA contacts to report that "inadequate understanding of new technology" was a very significant or significant barrier to their programs. A minimal amount of 
WVEEA contacts felt that "volunteer burnout" was a very significant barrier, while more than a third of the extension agents felt that it was a very significant barrier to their programs.

Some of the differences in barriers noted between the WVEEA contacts and the WVU Extension Agents could likely be due to the fact that the WVU Extension Agents and the 4-H programs do not primarily focus on environmental education programs even though they are involved. Extension agents are involved in several types of environmental education programs through 4-H programs and the community, but have a variety of other issues they help the communities with such as agriculture, health, nutrition and development. Because there are so many different types of programs that Extension Agents deal with, their volunteers are more likely to get burned out, since they are spread thin through all the various activities and not just environmental education programs.

The differences in the responses to this question could also in part come from the fact that the extension agents are part of the West Virginia University Extension Service and do receive support from the University, where as the WVEEA contacts are not all members of one supportive organization. West Virginia extension agents get 4-H project books and program curriculum from West Virginia University. Instead of having to go out and find all new information or create their own programs all the time, they are given the opportunity to use WVU as a resource. The WVEEA contacts do not currently have that type of opportunity yet. One goal of the WVEEA could be to become an organization where their members can gain support similar to that of the WVU extension agents.

Even though there were several differences among the responses of the two groups, there were many similarities. A third of the WVEEA and nearly half of Extension respondents reported that "Teachers lack time to fully participate in programs" as a "very significant barrier". 
Both groups also noted that "Escalating busing costs means fewer site visits" was a "very significant" barrier. Nearly half of the WVEEA contacts and extension agents felt that "partnership creation takes time and is difficult" was a significant barrier to their respective programs. Both the WVEEA contacts and extension agents felt that "lack of time to plan, develop or update programs" was a significant barrier to the success of their programs. In addition, a third of both the WVEEA contacts and extension agents felt that "lack of funding for programs" was a significant barrier to their programs.

Both groups reported teacher's time and busing costs as barriers to their programs, which suggests potential issues with the school system that could be addressed. Over the past few years, the rising cost of fuel has hampered the field trip budget that county school systems have for their students. There have been priorities put on bus trips, and unfortunately, it seems that educational field trips get cut. One potential solution is the groups providing environmental education opportunities develop "moving programs" that could be taken to schools. If teachers cannot come to the program location, the program could potentially go to them. For example, the West Virginia Farm Bureau has a mobile Agriculture Education Science Lab that travels to schools across the state throughout the school year, as well as to fairs and festivals during the summer. Mobile programs could be tough for some programs, but in order to keep programs going, adjustments might have to be made. There is always the option to work along with the county school system to work out some busing, or other, options.

The similarities in the responses show that the WVEEA could not only be supportive of new members, but also of the WVU Extension Service to help better supply extension agents with needed information on environmental education issues that are not provided by WVU. 
Both groups were asked was about the needs they had concerning professional development opportunities that would help with their environmental education programs. There were several opportunities listed, and again the responses showed similarities and differences among the groups. The differences in the need for certain professional development opportunities were interesting. For example, nearly half of the WVEEA contacts felt that "moving from ideas to actions: how to optimize your program to maximize environmentally responsible behavior" was a very valuable professional development opportunity compared to less than a quarter of the extension agents. Nearly half of the extension agents felt that "youth engagement; how to communicate with youth and engage them in your program and planning" was a very valuable professional development opportunity, while only a quarter of the WVEEA contacts believed it was a very valuable opportunity. A final example shows that a smaller percentage of the WVEEA contacts felt that "how to improve your program, based on current research and what is known about environmental education" was a very valuable or valuable professional development opportunity compared to the extension agents, even though both groups had a majority that felt this was valuable.

This difference in the value placed on "improving programs based on current research" could stem from the requirement that extension agents provide information based on research. This is also likely why the extension agents were more interested in how to improve their programs based on current research in environmental education. Youth development is also a very important aspect of Extension Service, so it is not surprising that any professional development opportunities on the subject would be at the top of their list.

There were more similarities among the two groups on the question concerning professional development opportunities than the barriers question. Over half of the WVEEA 
contacts and extension agents felt that "The NAAEE guidelines for excellence in environmental education; how to use them, how to adapt them to WV" was a valuable professional development opportunity. Almost a quarter of both the WVEEA contacts and extension agents felt that "How to reach and broaden your audience" was a very valuable professional development opportunity. One other similarity is that there were very few from either group that chose any of the opportunities as being "not valuable", which potentially reveals that the majority of respondents to both surveys have an interest in any professional development opportunities that might be provided.

When asked about capacity building, the highest ranking opportunities for WVEEA contacts were "project/program planning and development" and "grant application and proposal writing." This makes sense because most of the time all program providers are looking for new ways to develop a program and for funding, so both of these opportunities are key—and ones that the WVEEA should consider providing.

A study done in 2001 of K-12 teachers in Northern Kentucky found similar results for needs (Meichtry, 2001). The top three needs found in this Northern Kentucky study were funding for activities and resources, field trip opportunities and curriculum resources. The WVEEA contacts wanted to take advantage of opportunities that provided information on how to get funding and on program development. Both of these capacity building needs are in line with needs the Northern Kentucky teachers expressed (Meichtry, 2001).

The WVEEA contacts provide a wide array of programs from water to energy issues. Where these program providers get their information could provide insight into how to better reach providers, or how to help them find relevant information. The respondents ranked how important each source was to their program. The sources that were most important, in order, 
were "personal contact with experts," "scientific studies and research," and "network meetings with colleagues." Other important sources were "electronic newsletters," "attending conferences," "training workshops," "electronic media” and "email list serves." Newer technologies seemed to be a trend. Communication is becoming more electronic in today's technology driven world. It stands to reason that most people want some type of electronic information source. Further evidence of this move to a technology age is seen by the respondents reporting that "paper newsletters" and "telephone conferencing" were not important sources of information for their programs.

Since the WVEEA is a newly formed organization, the contacts for the organization were asked several questions that will hopefully guide the strategic direction of the new organization. When asked what they felt the role of the WVEEA should be, respondents indicated that the most important role of the WVEEA should be to "facilitate leadership", followed by "connect to the wider EE community," "increase capacity," "build state networks" and "champion environmental education."

The contacts were also asked who they felt should be the primary membership of the WVEEA. Respondents frequently indicated that teachers and educators should compose the main membership of the WVEEA, but also noted that any individual or organization providing environmental education, and agency workers should be part of the membership as well. When asked about expectations of a WVEEA membership, those that responded to the question reported they would like to receive networking opportunities, professional development opportunities and felt they would gain resources through an organization membership. A study done in Pennsylvania for the Center of Environmental Education (Johnson, 1997) found that the highest perceived environmental education need in the state was 
professional development, and over half of the respondents in the same study favored the development of a resource directory networking tool. A separate study done for the Pennsylvania Center of Environmental Education (Meredith \& Best, 2000) found that respondents would be interested in going to workshops with suggested content including networking. These studies have found that the barriers that educators run into lead them to the need for professional development and networking opportunities to improve their knowledge and programs. As noted above, WVEEA respondents also indicated that networking and professional development opportunities would be important benefits that the WVEEA could provide.

Based on much of the information found in this study, the WVEEA should have a good starting point to developing their organization further. It seems that the organization would want to focus their attention toward teachers and program educators as their biggest portion of membership, but remain open to any interested organization or individual. Once they get a membership established, they can then work with the members to form ways of networking with each other and other environmental education professionals. Also, these networking opportunities might bring out individuals or organizations that could help provide some professional development programs for the members. By doing this, the West Virginia Environmental Education Association will be better able to facilitate leadership among West Virginia environmental education communities.

\section{Conclusions}

The West Virginia Environmental Education Association is a network of environmental education professionals who collaborate to strengthen the environmental community in West 
Virginia (WVEEA, 2009). The mission of the WVEEA is to promote awareness, knowledge, and responsible action towards the natural world through a statewide network of support for environmental education professionals. Their vision is "to conserve West Virginia's natural and cultural heritage by fostering an environmentally literate and responsible public accomplished through connecting, training, and supporting a community of stewards through education in order to promote an environmentally aware and responsible citizenry” (WVEEA, 2009).

Since the WVEEA is a newly formed organization, they are looking for direction in who to target for a membership base and what their role should be in the state's EE community. This study has focused on these topics to give the organization assistance in deciding what their next steps should be. The WVEEA doesn't currently have members, but does have contacts that are interested in West Virginia environmental education and potentially becoming members. The surveys collected during this research can help the WVEEA determine what types of individuals and organizations are interested in becoming members and what they would like to receive in return for becoming a member of the organization.

Once the WVEEA starts creating a membership base, they will then be able to offer several opportunities to those that choose to become members. One thing that was strongly noted was that members would expect to receive networking opportunities and professional development opportunities (Johnson, 1997; Meredith \& Best, 2000). The respondents to the surveys indicated several professional development opportunities that they felt would be very valuable to their programs - such as improving their programs based on current research and maximizing environmentally responsible behavior in their programs. The WVEEA should be able to take some of these suggestions and create a variety of useful opportunities for their members. 
The information collected through this study will be given to the WVEEA to help continue building their organization. An abbreviated version of the results and discussion section of this thesis will be made available for the WVEEA as well as access to the entire thesis. The WVEEA has a newly created website where they will post both versions for all environmental educators in West Virginia to view.

The results from this study should also be beneficial to the Extension Service at West Virginia University. This study has shown that environmental educators don't view extension agents as a valuable source of information for their programs. These results could give WVU Extension information on programs that are conducted in the state and how they could potentially provide information or support for some programs. Extension allows a link to West Virginia University resources, which many environmental educators indicated would be very valuable.

\section{Recommendations}

The main recommendations would be for the WVEEA to use the findings from this study to help build a membership base, and begin providing networking and professional development opportunities. In addition, it is recommended that the WVEAA continue to assess its development as it grows. This study has hopefully given the WVEEA some direction in further development of their organization with the creation of a membership base and professional development opportunities. A future study could determine what benefits the members are actually receiving from the organization and compare that to the responses of what they had hoped to receive from the WVEEA in this study. Also, future studies could determine if the WVEEA provided the professional development opportunities suggested by this research. In 
addition, there is then the opportunity to get responses from those that participated in the professional development seminars to see if it helped their program advance or improve in any way.

This study could also be reproduced in other states to see if similar results are found. Other states might find that environmental educators have better relationships with their Extension Service. Similar organizations to the WVEEA in other states may be more developed, but might find this study useful to provide better support for their environmental education providers. 


\section{REFERENCES}

ACEE. (2006). Needs Assessment Survey. (Available from the Alberta Council for Environmental Education).

Angell, T. (2002). Summary of the 2001-2002 Washington State Environmental Education Needs Assessment Survey. Northwest Environmental Education Council/Washington State Office of Environmental Education.

Associated Press. (2009). 1 in 5 Preschoolers is Obese, Study Finds: Among American Indian children, Rate makes Surprising Jump to one-third. Retrieved from the World Wide Web April 19, 2009: http://www.msnbc.msn.com/id/30072958/wid/11915773/.

Caravella, J., (2006). A Needs Assessment Method for Extension Educators. Journal of Extension. 44(1).

Climate Change Education.org. (2009). Global Warming Education, Climate Change Education, Science, Solutions-Resource Directory. Retrieved from the World Wide Web April 26, 2009: http://climatechangeeducation.org/.

Costello, R. B. (Ed.). (1993). The American Heritage College Dictionary ( $3^{\text {rd }}$ ed.). Boston: Houghton Mifflin Company.

Dillman, D. (2007). Mail and Internet surveys: The Tailored Design Method. Second Edition. Hoboken, NJ: John Wiley \& Sons, Inc.

Dodd, A., Abdalla, C. (2004). Strengthening Environmental Policy Education through Qualitative Research: Experience with Pennsylvania's Nutrient Management Act Regulatory Review. Journal of Extension. 42(5).

Dohney, K. (2005). 'No Child Left Behind,' but Physical Activity may Suffer. Scout News, LLC. Retrieve from the World Wide Web April 30, 2009: http://sexualhealth.ehealthsource.com/index.php?p=news $1 \& \mathrm{id}=525549$

Enhancing Education. (2002). Formal vs. Informal Education. Retrieved from the World Wide Web April 15, 2008: http://enhancinged.wgbh.org/started/what/formal.html.

Environmental Education and Training Partnership. (2002). Environmental Education Liaison with State Capacity Building: A National survey of Project Learning Tree, Project Wet, Project Wild, and World Wildlife Fund Environmental Education Providers.

Gardner, B. \& Verrier, J. (2002). Effective and Responsive Needs Assessment. Ontario Legislative Library, Legislative Assembly of Ontario, Toronto, Canada. 
Graziano, A., \& Raulin, M. (1997). Research Methods: A process of inquiry. New York: Longman.

Green Facts: Facts on Health and the Environment. (2007). Scientific Facts on Climate Change. Retrieved from the World Wide Web April 26, 2009: http://www.greenfacts.org/studies/climate_change/level_1.htm\#2.

Iannelli, Vincent, M.D. (2008). Childhood Obesity - Child Obesity Statistics: Child Obesity Basics. Retrieved April 26, 2009 from the World Wide Web: http://pediatrics.about.com/od/obesity/a/obesity_stats.htm.

IPCC (2007). Climate Change 2007: Synthesis Report. Contribution of Working Groups 1, 2 \& 3 to the Fourth Assessment Report of the Intergovernmental Panel on Climate Change. (Core Writing Team, Pachauri, R.K. \& Reisinger, A., eds.). IPCC, Geneva, Switzerland, 104 pp.

Johnson, P. (1997). A Needs Assessment for the Pennsylvania Center for Environmental Education. Pennsylvania Center for Environmental Education.

King, Ledyard. (2008). Environmental Education gets a Green Light. Gannett News Service. Retrieved from the World Wide Web April 19, 2009: http://www.usatoday.com/news/education/2008-07-31-environmental-learning_N.htm.

Koukel, S.D., \& Cummings, M.N. (2002). New Mexico Cooperative Extension Service home economists' perceived technical knowledge and estimated client needs. Journal of Extension, 40(5).

Lawrence Berkeley National Laboratory. (2008). Basic vs. Applied Research. Retrieved from the World Wide Web April 15, 2008: http://www.lbl.gov/Education/ELSI/research-main.html.

Lawrence, J.D., Schuknecht, S., Lally, J. (2006). Voluntary Environmental Improvement Programs: Teaching Them to Fish or Providing a Professional Guide. Journal of Extension, 44(6).

Lieberman, G. \& Hoody, L. (1998). Closing the achievement gap: Using the environment as an integrating context for learning. Poway, CA: Science Wizards.

Louv, R. (2005). Last Child in the Woods. Chapel Hill, NC: Algonquin Books.

Maller, C., Townsend, M., St.Leger, L., Henderson-Wilson, C., Pryor, A., Prosser, L., and Moore, M. (2008). The health benefits of contact with nature in a park context: A review of relevant literature. Deakin University and Parks Victoria. 108 pp.

Meichtry, Y. (2001). An Environmental Education Needs Assessment of K-12 Teachers. Northern Kentucky University. Proceedings of the Annual Meeting of the Association for the Education of Teachers in Science. 
Meredith, J., Best, H. (2000). Report on the Needs Assessment for the Professional Development Initiative of the Pennsylvania Center for Environmental Education. Pennsylvania Center for Environmental Education.

Monroe, M. C., \& Randall, J., Crisp, V. (2001). Improving Achievement with Environmental Education. University of Florida Institute of Food and Agriculture Sciences Extension. Retrieved December 3, 2007 from the World Wide Web: http://edis.ifas.ufl.edu/FR114.

No Child Left Inside. (2009). Childhood Obesity. Retrieved April 26, 2009 from the World Wide Web: http://www.cbf.org/site/PageServer?pagename=act_sub_actioncenter_federal_nclb_obesity.

North American Association of Environmental Educators. (2009). Promoting Excellence in Environmental Education. Retrieved March 29, 2009 from the World Wide Web: http://www.naaee.org/.

Phibbs, E., \& Relf, D., \& Hunnings, J. (2005). Implementing a Needs Assessment for LongTerm Strategic Planning in 4-H Horticulture Programming. Journal of Extension. 43(4).

Rouda, R.H., \& Kusy, M.E. (1995). Needs Assessment: The First Step. Tappi Journal, 1995.

Russell, B. (1995). Swatting flies-eating elephants. Journal of Extension, 33(5).

Skelly, S.M., \& Zajeicek, J.M. (1998). The effect of an interdisciplinary garden program on the environmental attitudes of elementary school students. HortTechnology. 8:579-583.

Summer Institute of Linguistics. (1999). Formal versus Nonformal Education. Retrieved via the World Wide Web April 15, 2008:

http://www.sil.org/lingualinks/literacy/PrepareForALiteracyProgram/FormalVersusNonformalEd ucation.htm.

United Nations Educational Scientific and Cultural Organizations. (1977). Conference on Environmental Education. Retrieved November 25, 2007 from the World Wide Web: http://portal.unesco.org/education.

United States Environmental Protection Agency. (2007). Environmental Education Basic Information. Retrieved November 25, 2007 from the World Wide Web:

http://www.epa.gov/enviroed/basic.html.

United States Environmental Protection Agency/Cooperative Extension Partnerships. (2000). Building Capacity: Educating for Community Action. No. 6.

United States Environmental Protection Agency/Cooperative Extension Partnerships. (2000). Building Capacity: Community-Based Environmental Education in Practice. No. 8. 
Urban Institute, The. (2001). Capacity Building in Nonprofit Organizations. Retrieved April 9, 2008 from the World Wide Web: http://www.urban.org/UploadedPDF/building_capacity.PDF.

Waters, R.G., Haskell, L.J. (1988). Identifying Staff Development Needs of Cooperative Extension Faculty Using a Modified Borich Needs Assessment Model. University of NevadaReno.

West Virginia Environmental Education Association. (2009). Retrieved March 22, 2009 from the World Wide Web: http://www.wveea.org/.

West Virginia, Wild and Wonderful. (2008). Retrieved April 15, 2008 from the World Wide Web: http://www.wvtourism.com/.

Wood-Arendt, A.E. (2003). The role of Outreach Education in achieving Environmental Literacy. Major paper submitted to the faculty of Virginia Polytechnic Institute and State University. 


\section{APPENDIX}

\section{WVEEA Questionnaire}

\section{First, a little about your organization}

1. How would you categorize your organization? (please check one box)
a. Government Agency
b. Private for profit group
c. Non-Profit Organization
d. University or college
e. Public School K-12
f. Private School K-12
g. University Extension Service
h. Funder
i. Other - Please specify

2. What major types of environmental issues or topics do your programs address? (check all that apply)

$\checkmark$ Water (water quality, watersheds, water cycle, etc.)

Air Quality

$\square \quad$ Plant Life

$\square \quad$ Wildlife

$\square$ Global warming

$\square$ Energy

Ecosystems/habitats

$\square$ Other - Please specify

3. What type of EE programming do you offer? (check all that apply)
In school activities
$\square$ Web Based
Day camps
$\square$ Children's programs
Residential camps
$\square$ Adult programs
Special events
$\square$ Other - Please specify:

4. When do you conduct your programs? (please check one)

$\square$ Year-round

$\square$ Seasonally only

$\square$ Other - Please briefly describe: 
5. In general, how often do you conduct programs/activities each year? (please check one)

One per year

2-6 per year

At least one per month

2-3 times per month

At least one per week

2-3 times per week

Daily

Other - Please specify:

6. On an annual basis, how many people participate in your programs? (please check one)

$0-100$

$\square \quad 101-250$

$\square \quad 251-500$

- 501-1000

$\square \quad 1001-5000$

$\square$ Over 5000

7. Do you conduct teacher trainings? (please check one)

$\square$ Yes $\rightarrow$ If yes, approximately how many teachers did you train last year?

$\square$ No

8. What areas of existing West Virginia curriculum do your programs currently address? (check all that apply)

$\square$ Elementary Science

$\square$ Elementary Social Studies

$\square$ Jr. High Science

$\square$ Jr. High Social Studies

High School Agri-Science

$\square$ High School Biology

$\square$ High School Chemistry

$\square$ High School Physics

$\square$ High School Social Studies

$\square$ Other (please specify):

$\square$ None - Please indicate why: 


\section{Now, about your Program Development Needs}

9. We'd like to know what barriers you come across in your work, and how significant they are to your organization.

(please circle the degree of significance for each barrier)

\begin{tabular}{|c|c|c|c|c|}
\hline & $\begin{array}{c}\text { Very } \\
\text { Significant }\end{array}$ & Significant & $\begin{array}{l}\text { A Little } \\
\text { Significant }\end{array}$ & $\begin{array}{c}\text { Not } \\
\text { Significant }\end{array}$ \\
\hline $\begin{array}{l}\text { a. Difficulty contacting and or engaging new } \\
\text { audiences }\end{array}$ & VS & $\mathrm{S}$ & LS & NS \\
\hline $\begin{array}{l}\text { b. Teachers lack time to fully participate in } \\
\text { programs }\end{array}$ & VS & $\mathrm{S}$ & LS & NS \\
\hline $\begin{array}{l}\text { c. Teachers lack interest to fully participate in } \\
\text { programs }\end{array}$ & VS & $\mathrm{S}$ & $\mathrm{LS}$ & NS \\
\hline $\begin{array}{l}\text { d. Inadequate background knowledge by } \\
\text { teachers }\end{array}$ & VS & $\mathrm{S}$ & LS & NS \\
\hline $\begin{array}{l}\text { e. Concerns over liability vis-à-vis outdoor } \\
\text { programs }\end{array}$ & VS & $\mathrm{S}$ & $\mathrm{LS}$ & NS \\
\hline $\begin{array}{l}\text { f. Escalating busing costs means fewer site } \\
\text { visits }\end{array}$ & VS & $\mathrm{S}$ & LS & NS \\
\hline $\begin{array}{l}\text { g. Lack of time to plan, develop or update } \\
\text { programs }\end{array}$ & VS & $\mathrm{S}$ & $\mathrm{LS}$ & NS \\
\hline $\begin{array}{l}\text { h. Lack of evaluation tools to measure } \\
\text { effectiveness and improve programs }\end{array}$ & VS & $\mathrm{S}$ & LS & NS \\
\hline $\begin{array}{l}\text { i. Partnership creation takes time and is } \\
\text { difficult }\end{array}$ & VS & $\mathrm{S}$ & $\mathrm{LS}$ & NS \\
\hline j. Lack of curriculum fit & VS & $\mathrm{S}$ & $\mathrm{LS}$ & NS \\
\hline k. Difficulty keeping staff & VS & $\mathrm{S}$ & LS & NS \\
\hline $\begin{array}{l}\text { 1. Lack of relevant professional development } \\
\text { for staff }\end{array}$ & VS & $\mathrm{S}$ & LS & NS \\
\hline $\begin{array}{l}\text { m. Don't hear about professional development } \\
\text { opportunities }\end{array}$ & VS & $\mathrm{S}$ & LS & NS \\
\hline n. Lack of funding for programs & VS & $\mathrm{S}$ & $\mathrm{LS}$ & NS \\
\hline o. Lack of funding for core operations & VS & $\mathrm{S}$ & $\mathrm{LS}$ & NS \\
\hline $\begin{array}{l}\text { p. Don't know what other organizations are } \\
\text { up to }\end{array}$ & VS & $\mathrm{S}$ & LS & NS \\
\hline $\begin{array}{l}\text { q. Inadequate understanding of new } \\
\text { technology }\end{array}$ & VS & $\mathrm{S}$ & $\mathrm{LS}$ & NS \\
\hline r. Lack of support within my organization & VS & $\mathrm{S}$ & LS & NS \\
\hline $\begin{array}{l}\text { s. Poor understanding of how to } \\
\text { define/implement "excellent environmental } \\
\text { education" }\end{array}$ & VS & $\mathrm{S}$ & $\mathrm{LS}$ & NS \\
\hline t. Low demand from key audiences & VS & $\mathrm{S}$ & LS & NS \\
\hline u. Staff burnout & VS & $\mathrm{S}$ & $\mathrm{LS}$ & NS \\
\hline v. Volunteer burnout & VS & $\mathrm{S}$ & LS & NS \\
\hline w. Other (please list) & VS & $\mathrm{S}$ & LS & NS \\
\hline
\end{tabular}


10. The following is a list of topics around which WVEEA could help provide professional development specific to your program(s). Please indicate the value of them as potential workshops/professional development offerings.

(please circle the appropriate response, according to your organization's needs)

\begin{tabular}{|c|c|c|c|c|}
\hline & $\begin{array}{c}\text { Very } \\
\text { Valuable }\end{array}$ & Valuable & $\begin{array}{l}\text { A Little } \\
\text { Valuable }\end{array}$ & $\begin{array}{c}\text { Not } \\
\text { Valuable }\end{array}$ \\
\hline $\begin{array}{l}\text { a. How to improve your program, based on current } \\
\text { research and "what is known" about } \\
\text { environmental education }\end{array}$ & VV & $\mathrm{V}$ & LV & NV \\
\hline $\begin{array}{l}\text { b. Moving from ideas to actions: how to optimize } \\
\text { your program to maximize environmentally } \\
\text { responsible behavior }\end{array}$ & VV & $\mathrm{V}$ & LV & NV \\
\hline $\begin{array}{l}\text { c. How to evaluate the success of your } \\
\text { environmental education program }\end{array}$ & VV & $\mathrm{V}$ & LV & NV \\
\hline $\begin{array}{l}\text { d. The guidelines for excellence in environmental } \\
\text { education: how to use them, how to adapt them } \\
\text { to WV }\end{array}$ & VV & $\mathrm{V}$ & LV & NV \\
\hline $\begin{array}{l}\text { e. Youth engagement: how to communicate with } \\
\text { youth and engage them in your program and in } \\
\text { your planning }\end{array}$ & VV & $\mathrm{V}$ & LV & NV \\
\hline $\begin{array}{l}\text { f. How to maintain a successful outdoor education } \\
\text { program }\end{array}$ & VV & $\mathrm{V}$ & LV & NV \\
\hline $\begin{array}{l}\text { g. Curriculum review: work to make changes to } \\
\text { emerging or existing curriculum }\end{array}$ & VV & $\mathrm{V}$ & LV & NV \\
\hline $\begin{array}{l}\text { h. How to provide and deliver effective teacher } \\
\text { training workshops }\end{array}$ & VV & $\mathrm{V}$ & LV & NV \\
\hline $\begin{array}{l}\text { i. How to design teaching resources (i.e., activity } \\
\text { book, multi-media, etc.) }\end{array}$ & VV & $\mathrm{V}$ & LV & NV \\
\hline j. How to reach and broaden your audience & VV & $\mathrm{V}$ & LV & NV \\
\hline $\begin{array}{l}\text { k. How to find quality, current research on } \\
\text { environmental issues }\end{array}$ & VV & $\mathrm{V}$ & LV & NV \\
\hline 1. Other (please list): & VV & V & LV & NV \\
\hline
\end{tabular}

11. Many of you have a high level of expertise in some of these areas - and we are interested in promoting collaborative approaches. Would you be willing to share what you know at a professional development session or an informal gathering? (check one box, and list topics if applicable)

$\square$ Yes $\rightarrow$ If so, please tell us which topics from the above list:

No 


\section{About your Organizational Development Needs}

The following questions will help us get a snapshot of your current organizational capacity.

12. What is happening with the demand for your education programs? (please check one)

Increasing

Decreasing

$\square$ Staying the same

13. Are you able to meet the demand for your programs? (please check one)

$\square$ Always

$\square \quad$ Very often

$\square$ Sometimes

$\square$ Rarely

$\square$ Never

14. How many staff members does your organization have (full/part time)?
Full-time: (please write in number)
Part-time: (please write in number)
$\square$ Volunteer: (please write in number)

15. In what range is your organization's annual operating budget? (If you work for a large agency with multiple departments - i.e., a state agency, etc. - please give your answer in regards to your education department/program's budget.) (please check one)

$\square$ Under $\$ 5,000$

$\square \$ 5,000-20,000$

$\square \$ 20,000-50,000$

$\square \quad \$ 50,000-100,000$

$\square \quad \$ 100,000-150,000$

$\square$ \$150,000-250,000

$\square$ Over $\$ 250,000$

$\square$ N/A 
16. In order to improve your organization's capacity, what priority would you place on training in the following areas?

\begin{tabular}{|l|c|c|c|c|}
\hline & $\begin{array}{c}\text { High } \\
\text { Priority }\end{array}$ & $\begin{array}{c}\text { Medium } \\
\text { Priority }\end{array}$ & $\begin{array}{c}\text { Low } \\
\text { Priority }\end{array}$ & $\begin{array}{c}\text { Not } \\
\text { Applicable }\end{array}$ \\
\hline Governance and/or leadership & HP & MP & LP & NA \\
\hline Board/leadership development & HP & MP & LP & NA \\
\hline Strategic planning & HP & MP & LP & NA \\
\hline $\begin{array}{l}\text { Project/program planning and/or } \\
\text { development }\end{array}$ & HP & MP & LP & NA \\
\hline Project management & HP & MP & LP & NA \\
\hline Financial management & HP & MP & LP & NA \\
\hline General fundraising & HP & MP & LP & NA \\
\hline $\begin{array}{l}\text { Grant application and/or proposal } \\
\text { writing }\end{array}$ & HP & MP & LP & NA \\
\hline Organizational promotion & HP & MP & LP & NA \\
\hline General communications & HP & MP & LP & NA \\
\hline Volunteer recruitment & HP & MP & LP & NA \\
\hline Volunteer management & HP & MP & LP & NA \\
\hline Evaluating success & HP & MP & LP & NA \\
\hline Human resources & HP & MP & LP & NA \\
\hline Staff retention & HP & MP & LP & NA \\
\hline $\begin{array}{l}\text { Collaboration with like-minded } \\
\text { colleagues }\end{array}$ & HP & MP & LP & NA \\
\hline $\begin{array}{l}\text { Collaboration with non-traditional } \\
\text { partners }\end{array}$ & HP & MP & LP & NA \\
\hline Other (please write in): & & & & \\
\hline
\end{tabular}


17. How important is each of the following as a source of information for your organization? (please circle the appropriate response for each)

\begin{tabular}{|l|c|c|c|c|}
\hline & $\begin{array}{c}\text { Very } \\
\text { Important }\end{array}$ & Important & $\begin{array}{c}\text { A Little } \\
\text { important }\end{array}$ & $\begin{array}{c}\text { Not } \\
\text { important }\end{array}$ \\
\hline Attending conferences & VI & I & LI & NI \\
\hline Training workshops & VI & I & LI & NI \\
\hline Email list serves & VI & I & LI & NI \\
\hline Electronic newsletters & VI & I & LI & NI \\
\hline Paper newsletters & VI & I & LI & NI \\
\hline County Extension Service \& Agents & VI & I & LI & NI \\
\hline Conducting internet research & VI & I & LI & NI \\
\hline Scientific studies and/or research & VI & I & LI & NI \\
\hline Mainstream print & VI & I & LI & NI \\
\hline Electronic media (web pages; blogs, etc.) & VI & I & LI & NI \\
\hline Specialty newsletters and periodicals & VI & I & LI & NI \\
\hline Personal contact with experts & VI & I & LI & NI \\
\hline Web or video conferencing & VI & I & LI & NI \\
\hline Telephone conferencing & VI & I & LI & NI \\
\hline Network meetings with colleagues & VI & I & LI & NI \\
\hline Other (please write in): & VI & I & LI & NI \\
\hline
\end{tabular}




\section{Feedback for the WVEEA}

18. WVEEA could potentially work in a variety of roles. Please indicate what you think WVEEA's role should be, with 1 being the most important and 5 being least important. (e.g. please put a number 1 in the box for the role you feel is the most important, 2 for the secondmost important, etc.)

\begin{tabular}{|l|l|}
\hline & $\begin{array}{c}\text { Place rank } \\
\text { number in } \\
\text { boxes (1-5) }\end{array}$ \\
\hline $\begin{array}{l}\text { Champion environmental education. WVEEA should be a voice for the } \\
\text { advancement of EE. }\end{array}$ & \\
\hline $\begin{array}{l}\text { Facilitate leadership. WVEEA will help develop and coordinate leadership } \\
\text { within the West Virginia EE community. }\end{array}$ & \\
\hline $\begin{array}{l}\text { Build state networks. WVEEA will develop, encourage and support a } \\
\text { statewide network of environmental education professionals that help the } \\
\text { exchange of information and provide for collaborative opportunities within } \\
\text { the EE community. }\end{array}$ & \\
\hline $\begin{array}{l}\text { Connect to the wider EE community. WVEEA will work with all interested } \\
\text { EE providers to promote resources, services, and events to the widest } \\
\text { possible audience of WV educators, and connect our efforts to relevant } \\
\text { national initiatives. }\end{array}$ & \\
\hline $\begin{array}{l}\text { Increase capacity. WVEEA will develop partnerships and mechanisms to } \\
\text { build capacity for, and help ensure, the continual improvement of EE groups. } \\
\text { WVEEA will provide professional development opportunities to a variety of } \\
\text { EE providers. }\end{array}$ & \\
\hline
\end{tabular}

19. Who do you think should be the primary membership base of the WVEEA? (please write in your response)

20. What benefits do you expect to receive from joining the WVEEA? (please write in your response) 
V. Non-profit groups ONLY (please skip to Question 24 if you do not work for a Non-Profit)

The following questions are for non-profit groups only.

21. What is the legal status of your organization? (please check one)

$\square$ Incorporated in WV as non-profit

A chapter or branch of an organization incorporated in another state

22. Does your organization have a charitable status? (please check one)

$\square$ Yes

$\square$ No

23. How many members does your organization have? (please type/write number)

\section{Finally, a few last questions about you specifically:}

24. Please select one or more of the following categories to best describe your race. (please check one or more)

$\square$ American Indian or Alaska native

Asian

Black or African American

$\square$ Native Hawaiian or Pacific Islander

$\square$ White/Caucasian

$\square$ Hispanic or Latino

25. What is the highest grade in school you have completed? (check one)

Some high school or less

High school graduate or GED

Some college

College graduate - Associate Degree

College Graduate - Bachelor Degree

Some graduate school

Graduate degree

Doctoral or professional degree

26. What is your age? (please write in your answer)

27. Are you: (check one)

$\square$ female

$\square$ male 
West Virginia University Extension Agent Questionnaire

\section{First, a little about your organization's programs}

1. Are you aware of any Environmental Education Programs that are conducted in your county? $\square \quad$ Yes (Continue with Q2)

$\square \quad$ No (Please skip to Q3)

2. If so, please list the programs you are aware of: (write in response)

3. Does your Extension Office provide materials and/or resources to any of these Environmental Education programs?

$\square \quad$ Yes (Continue with Q4)

$\square \quad$ No (Please skip to Q5)

4. Where do the materials/resources you provide come from? (write in response) 
5. The following is a list of topics around which WVEEA could help provide professional development specific to program(s) in your county. Please indicate the value of them as potential workshops/professional development offerings. (please circle the appropriate response, according to your organization's needs)

\begin{tabular}{|c|c|c|c|c|}
\hline & $\begin{array}{c}\text { Very } \\
\text { Valuable }\end{array}$ & Valuable & $\begin{array}{l}\text { A Little } \\
\text { Valuable }\end{array}$ & $\begin{array}{c}\text { Not } \\
\text { Valuable }\end{array}$ \\
\hline $\begin{array}{l}\text { a. How to improve your program, based on current } \\
\text { research and "what is known" about environmental } \\
\text { education }\end{array}$ & VV & $\mathrm{V}$ & LV & NV \\
\hline $\begin{array}{l}\text { b. Moving from ideas to actions: how to optimize } \\
\text { your program to maximize environmentally } \\
\text { responsible behavior }\end{array}$ & VV & $\mathrm{V}$ & LV & NV \\
\hline $\begin{array}{l}\text { c. How to evaluate the success of your environmental } \\
\text { education program }\end{array}$ & VV & $\mathrm{V}$ & LV & NV \\
\hline $\begin{array}{l}\text { d. The NAAEE guidelines for excellence in } \\
\text { environmental education: how to use them, how to } \\
\text { adapt them to WV }\end{array}$ & VV & $\mathrm{V}$ & LV & NV \\
\hline $\begin{array}{l}\text { e. Youth engagement: how to communicate with } \\
\text { youth and engage them in your program and in } \\
\text { your planning }\end{array}$ & VV & $\mathrm{V}$ & LV & NV \\
\hline $\begin{array}{l}\text { f. How to maintain a successful outdoor education } \\
\text { program }\end{array}$ & VV & $\mathrm{V}$ & LV & NV \\
\hline $\begin{array}{l}\text { g. Curriculum review: work to make changes to } \\
\text { emerging or existing curriculum }\end{array}$ & VV & $\mathrm{V}$ & LV & NV \\
\hline $\begin{array}{l}\text { h. How to provide and deliver effective teacher } \\
\text { training workshops }\end{array}$ & VV & $\mathrm{V}$ & LV & NV \\
\hline $\begin{array}{l}\text { i. How to design teaching resources (i.e., activity } \\
\text { book, multi-media, etc.) }\end{array}$ & VV & $\mathrm{V}$ & LV & NV \\
\hline j. How to reach and broaden your audience & VV & $\mathrm{V}$ & LV & NV \\
\hline $\begin{array}{l}\text { k. How to find quality, current research on } \\
\text { environmental issues }\end{array}$ & VV & $\mathrm{V}$ & LV & NV \\
\hline 1. Other (please list): & VV & $\mathrm{V}$ & LV & NV \\
\hline
\end{tabular}

6. Many of you have a high level of expertise in some of these areas - and we are interested in promoting collaborative approaches. Would you be willing to share what you know at a professional development session or an informal gathering? (check one box, and list topics if applicable)

Yes $\rightarrow$ If so, please tell us which topics from the above list:

No 
7. We'd like to know what barriers you have come across in your work with Environmental Education programs in your county and how significant they are. (please circle the degree of significance for each barrier)

\begin{tabular}{|c|c|c|c|c|}
\hline & $\begin{array}{c}\text { Very } \\
\text { Significant }\end{array}$ & Significant & $\begin{array}{l}\text { A Little } \\
\text { Significant }\end{array}$ & $\begin{array}{c}\text { Not } \\
\text { Significant }\end{array}$ \\
\hline $\begin{array}{l}\text { a. Difficulty contacting and or engaging new } \\
\text { audiences }\end{array}$ & VS & $\mathrm{S}$ & LS & NS \\
\hline $\begin{array}{l}\text { b. Teachers lack time to fully participate in } \\
\text { programs }\end{array}$ & VS & $\mathrm{S}$ & LS & NS \\
\hline $\begin{array}{l}\text { c. Teachers lack interest to fully participate in } \\
\text { programs }\end{array}$ & VS & $\mathrm{S}$ & LS & NS \\
\hline $\begin{array}{l}\text { d. Inadequate background knowledge by } \\
\text { teachers }\end{array}$ & VS & $\mathrm{S}$ & LS & NS \\
\hline $\begin{array}{l}\text { e. Concerns over liability vis-à-vis outdoor } \\
\text { programs }\end{array}$ & VS & $\mathrm{S}$ & LS & NS \\
\hline $\begin{array}{l}\text { f. Escalating busing costs means fewer site } \\
\text { visits }\end{array}$ & VS & $\mathrm{S}$ & LS & NS \\
\hline $\begin{array}{l}\text { g. Lack of time to plan, develop or update } \\
\text { programs }\end{array}$ & VS & $\mathrm{S}$ & LS & NS \\
\hline $\begin{array}{l}\text { h. Lack of evaluation tools to measure } \\
\text { effectiveness and improve programs }\end{array}$ & VS & $\mathrm{S}$ & LS & NS \\
\hline $\begin{array}{l}\text { i. Partnership creation takes time and is } \\
\text { difficult }\end{array}$ & VS & $\mathrm{S}$ & LS & NS \\
\hline j. Lack of curriculum fit & VS & $\mathrm{S}$ & LS & NS \\
\hline k. Difficulty keeping staff & VS & $\mathrm{S}$ & LS & NS \\
\hline $\begin{array}{l}\text { 1. Lack of relevant professional development } \\
\text { for staff }\end{array}$ & VS & $\mathrm{S}$ & LS & NS \\
\hline $\begin{array}{l}\text { m. Don't hear about professional development } \\
\text { opportunities }\end{array}$ & VS & $\mathrm{S}$ & LS & NS \\
\hline n. Lack of funding for programs & VS & $\mathrm{S}$ & $\mathrm{LS}$ & NS \\
\hline o. Lack of funding for core operations & VS & $\mathrm{S}$ & $\mathrm{LS}$ & NS \\
\hline $\begin{array}{l}\text { p. Don't know what other organizations are } \\
\text { up to }\end{array}$ & VS & $\mathrm{S}$ & LS & NS \\
\hline $\begin{array}{l}\text { q. Inadequate understanding of new } \\
\text { technology }\end{array}$ & VS & $\mathrm{S}$ & LS & NS \\
\hline r. Lack of support within my organization & VS & $\mathrm{S}$ & $\mathrm{LS}$ & NS \\
\hline $\begin{array}{l}\text { s. Poor understanding of how to } \\
\text { define/implement "excellent environmental } \\
\text { education" }\end{array}$ & VS & $\mathrm{S}$ & LS & NS \\
\hline t. Low demand from key audiences & VS & $\mathrm{S}$ & $\mathrm{LS}$ & NS \\
\hline u. Staff burnout & VS & $\mathrm{S}$ & $\mathrm{LS}$ & NS \\
\hline v. Volunteer burnout & VS & $\mathrm{S}$ & LS & NS \\
\hline w. Other (please list): & \multirow[b]{2}{*}{ VS } & \multirow[b]{2}{*}{$\mathrm{S}$} & \multirow[b]{2}{*}{ LS } & \multirow[b]{2}{*}{ NS } \\
\hline & & & & \\
\hline
\end{tabular}




\section{Finally, a few questions about you:}

8. Please select one or more of the following categories to best describe your race. (please check one or more)

$\square$ American Indian or Alaska native

$\square$ Asian

$\square$ Black or African American

$\square$ Native Hawaiian or Pacific Islander

$\square \quad$ White/Caucasian

$\square$ Hispanic

$\square \quad$ Latino

$\square$ Other

9. What is the highest grade in school you have completed? (check one)

$\square \quad$ Some high school or less

$\square$ High school graduate or equivalency

$\square$ Some college

$\square$ Associate degree

$\square$ Bachelor degree

$\square \quad$ Some graduate school

$\square$ Graduate degree

$\square$ Doctoral or professional degree

10. What is your age? (please write in your answer)

11. Are you: (check one)

$\square$ Female

$\square$ Male 